\title{
The Presence of Incumbents Electoral Competition and Reelection in Brazil (1990-2014)
}

\author{
José Alexandre da Silva Junior ${ }^{1}$ \\ https://orcid.org/0000-0002-6068-7460 \\ Leonardo Rodrigues Morais ${ }^{2}$ \\ https://orcid.org/0000-0002-2207-0611 \\ Ranulfo Paranhos ${ }^{1}$ \\ https://orcid.org/000-0002-0160-0011 \\ Albany Ferreira Lima ${ }^{3}$ \\ https://orcid.org/0000-0002-9346-4044
}

\begin{abstract}
${ }^{1}$ Universidade Federal de Alagoas, Social Science Institute, Maceió/AL, Brazil ${ }^{2}$ Universidade de Brasília, Political Science Institute, Brasília/DF, Brazil ${ }^{3}$ Universidade Federal de Minas Gerais, Pedagogical Center, Belo Horizonte/MG, Brazil
\end{abstract}

What are the effects of attempts at reelection on electoral competition? We have tested the assumption that attempts at reelection have a positive and significant effect on electoral competition. We measured electoral competition using two indicators: Imbalance index T (Taagepera) and generalized concentration index (Herfindahl-Hirscham $(\mathrm{HH})$ ). We analyzed data on the seven last Brazilian national elections (1990-2014). We employed descriptive (variable measures and times series) and inferential statistics (regression analysis with panel data). Our main findings: 01 . the percentage and the concentration of incumbents has a significant and negative effect on the concentration of votes; 02 . the interaction between the percentage of incumbents in a given dispute and in a coalition has a significant and positive effect on the concentration of votes.

Keywords: Competition; reelection; electoral system, indexes.

http://doi.org/ 10.1590/1981-3821202000010003

For data replication, see: https://doi.org/10.7910/DVN/FOHODB

Correspondence: José Alexandre da Silva Junior. E-mail: jose.junior@ics.ufal.br

This publication is registered under a CC-BY Licence. 
$\mathrm{n}$ uninominal districts, the presence of incumbents often has a significant and negative effect on electoral competition (ABRAMOWITZ, 1991; ABRAMOWITZ et al., 2006; FEREJONH, 1977; GLAZER et al., 1987; LYONS and GALDERISI, 1995; MAYHEW, 1974; TUFTE et al., 1974). The literature points out that candidates for reelection bring together reputation, personal attributes, and an ability to ward off good opponents. As a result, the electoral advantages enjoyed by incumbents vis-à-vis challengers grow over time, and electoral competition is continually reduced (ABRAMOWITZ, 1991; ABRAMOWITZ et al., 2006; CAMPBELL and JUREK, 2003; COX and KATZ, 1996; KAZEE, 1983; MAYHEW, 1974). Conversely, there is no evidence of such a relationship in multinomial districts. In this context, most of the literature on the subject is concerned only with incumbents' electoral advantage over challengers (ABRÚCIO and SAMUELS, 1997; AMES, 2003; PEREIRA and MULLER, 2003; PEREIRA and RENNÓ, 2003, 2007; SAMUELS, 2003; SANTOS, 2003). Generally speaking, the findings are controversial and end up limiting research into related themes. In summary, little is known about the electoral performance of incumbents in multinominal districts, and even less is known about the influence of this group of candidates on electoral competition.

In Brazil, the literature has not systematically investigated the relationship between the two phenomena. More specifically, works on electoral competition tend not to treat the presence of candidates for reelection as an explanatory variable. For the most part, they focus on the effects of the Open List Proportional Representation (OLPR) system. The prevailing view is that OLPR increases intraparty competition, weakens parties, and increases the personalization of electoral disputes (AMES, 1995, 2003; CARVALHO, 2003; LAMOUNIER, 1994; MAINWARING, 2001). It also encourages candidates to focus on the geo-spatial concentration of votes (CAMPELLO e ZUCCO, 2008; JACOB et al., 2009). In particular, it is believed that the candidates for reelection have an interest in maintaining the status quo. For example, Ames (2003) believes that incumbents strive to conserve their political 'grotões', i.e. zones of political dominance. Consequently, the electoral performances of incumbents tend to have a negative influence on electoral competition. 
In this work, we test the hypothesis that the concentration of incumbents in parties/coalitions has a negative and significant effect on electoral competition. To do this, we calculated the imbalance and concentration of votes using the indexes proposed by Taagepera (1979). We added control variables and tested the relationship between these indexes and the proportion and concentration of candidates for reelection. The results suggest that the concentration of votes is the most sensitive index for measuring the distribution of votes and that the proportion and the concentration of incumbents both have significant effects on electoral competition.

The text is organized in four sections. In the first, we present studies on the Brazilian electoral system with a focus on electoral competition. Next, we review the international debate that relates congressional reelection to electoral competition. The third section presents our methodology and empirical analysis. Our final considerations are presented in the conclusion.

\section{Competition and the electoral system}

The effects of electoral rules on the functioning of the political system has become a recurrent theme in Political Science. Duverger's pioneering work (1954) revealed the impact of the electoral formulae on numbers of parties, thus blazing a trail for further research. Rae (1967) and Lijphart (1990) went on to investigate the effects of such formulae, electoral district magnitude, and voting structures on proportionality and party numbers. While not unanimous on every aspect of the topic, both researchers concluded that electoral rules have significant effects on election results. Carey and Shugart (1995) examined the effects of electoral rules on vote personalization. They found that there is often a tension between the collective interests of political parties and the individual ones of party members. Electoral dispute outcomes turn on both party and personal reputations.

Carey and Shugart (1995) looked at four electoral system characteristics as a means of estimating this relationship: 01. party leader control over electoral lists; 02. vote aggregation units for conversion into seats; 03. vote type; and 04. district magnitude. They concluded that the most personalized systems are those where: 
01. leaders have little/no control over lists; 02. seats are allocated according to candidates' individual performance; 03. votes are conferred on candidates; and 04. districts are high-magnitude. Carey and Shugart (1995) also argued that legislators' efforts to build up their personal reputations increase during reelection campaigns. Fiorina (1977), Cox (1997), Katz (2005) and others believe that candidates tend to prioritize individual interests in reelection campaigns.

Brazil is no different. Overall, the literature demonstrates that the OLPR system combined with high-magnitude districts drives personalization of the vote (AMES, 2003; NICOLAU, 2006). On the one hand, the system allows all candidates to compete against each other. On the other hand, the vast majority of votes are cast on the basis of personality. Consequently, the focus of an election moves from political parties to the individuals representing them. This is reinforced by the fact that campaigns are organized and financed by candidates. In effect, the system drives personalization of the vote. Quite reasonably, candidates tend to engage in the creation/maintenance of their personal reputations at the expense of their party affiliations. Their prime imperative is to achieve the best possible position on the electoral list. Most elections involve a plethora of candidates distinguishable in voters' eyes by their names alone. To win, candidates not only need their party/coalition to win seats, but also to rank among 'the most voted for' (NICOLAU, 2006).

Furthermore, the Brazilian system treats incumbent candidates as it does all others. For this reason, some scholars argue that members of Congress (MoCs) seek to create/maintain zones of political dominance through allocation of resources. They believe that legislators seek to control these strongholds by swapping 'pork' for votes (AMES, 2003; BORGES, PAULA AND SILVA, 2016; PEREIRA and MULLER, 2003; PEREIRA and RENNÓ, 2007; SANTOS, 2003). The advantages enjoyed by incumbents are linked to 'favors' from the Executive branch of government rather than party affiliation or political positioning 1 . In this scenario, the president, governors, mayors and local leaders become key figures in

\footnotetext{
${ }^{1}$ We would like to express our thanks to an anonymous reviewer, who reminded us to emphasize the dependence of Brazilian MoCs on the Executive, for the inclusion of this passage.
} 
the political survival of MoCs. According to the literature, help from these key figures is indispensable if MoCs are to be able to provide evidence of benefits provided to their voter bases (ABRÚCIO and SAMUELS, 1997; BORGES, PAULA AND SILVA, 2016; SAMUELS, 2003). Incumbent candidates tend to maintain or expand their strongholds - and this in turn leads to reduced space for competition (AMES, 2003; MELO, 2004). Borges, Paula and Silva (2016) demonstrate that votes for incumbents are both more widespread and more dominant. Votes for incumbents tend to be spread widely across an electoral district and to dominate a larger number of key municipalities. It was our hypothesis that this configuration has a negative effect on electoral competition in Brazil's states.

By contrast, Kinzo et al. (2004) argue that the high degree of party fragmentation seen in the Brazilian Congress provides proof of the existence of competition. Others make similar arguments for the high levels of electoral volatility among parties (BRAGA, 2006; BOHN and PAIVA, 2009; MAINWARING, 1998). Limongi (2006) found competition present in a detailed analysis of municipal-level vote distribution in congressional elections. According to him, noncompetitive electoral coalitions were present in only 320 of the 5,665 municipalities analyzed ${ }^{2}$. Limongi (2006) shows that approximately $1.7 \%$ of the voters who came out to the polls in the 2002 election came from noncompetitive municipalities. Likewise, Silva (2013) demonstrates that the absence of competition is not the norm in congressional races. According to Silva (2013), competition levels have been on the increase since 1994. Avelino, Biderman and Silva (2016) investigated the concentration of votes among congressional candidates and found a generalized reduction in the magnitude of this measure. According to them, both candidates elected to office and their defeated rivals reduced their vote concentration levels. Furthermore, they have shown that deconcentration is the dominant strategy among victorious candidates (AVELINO, BIDERMAN and SILVA, 2016). Finally, Silva (2017) shows that district magnitude is a central element in any explanation of candidates' vote 
concentrations. Due to magnitude, where state and federal congressional candidates compete in the same district, votes for state representatives tend to be more concentrated (SILVA, 2017).

Furthermore, there is a body of work that questions whether MoCs have the capacity to and/or interest in creating/maintaining electoral strongholds (ABRÚCIO and SAMUELS, 1997; AVELINO, BIDERMAN and BARONE, 2012; CARNEIRO and ALMEIDA, 2008; FIGUEIREDO and LIMONGI, 2008; SAMUELS, 2003). In the first place, the electoral return of 'pork' in Brazil comes under attack. According to Samuels (2001), the large number of actors with an interest in claiming credit for purported benefits makes it difficult to turn pork into votes, especially in the absence of support from the mayors and governors (ABRÚCIO and SAMUELS, 1997). There also are doubts about MoCs' interest in focusing on benefits. As the system allows a voter from any part of an electoral district (a 'Federal Unit' in Brazilian terminology) to vote for any candidate, focusing on benefits is not always the best strategy (AVELINO, BIDERMAN and SILVA, 2016; FIGUEIREDO and LIMONGI, 2008).

Finally, Carneiro and Almeida (2008) show that political parties manage to bypass the parts of the Brazilian political system that would tend to hobble them. Indeed, political parties have demonstrated that electoral performances in past elections at state and federal levels are good predictors of a party's performance in municipal elections (CARNEIRO and ALMEIDA, 2008). Avelino, Biderman and Barone (2012) complement this view by demonstrating reverse coattails effects ${ }^{3}$ from mayors to state and federal legislators. They show that winning a mayoral office is an important step in a party improving its electoral performance in elections to state and federal legislatures. More than that, the findings of Avelino, Biderman and Barone (2002) weigh up the idea that vote concentration is the dominant strategy used by candidates for federal Congress.

\footnotetext{
${ }^{3}$ The term 'coattails' refers to the ability of a political leader or candidate to increase the chance of victory for other candidates from the same political party or coalition by virtue of his/her popularity.
} 
They conclude that chances improve when a party controls the local city council (AVELINO, BIDERMAN and BARONE, 2012).

In summary, a part of the literature on the subject assumes that the Brazilian electoral system encourages personalism. The interest of candidates in the formation of political 'grotões' is a consequence of this. Therefore, it further assumes that: 01. electoral competition tends to be 'banned' from some strongholds (micro-regions/municipalities), and 02. incumbent candidates are the main culprits. As shown above, there also exists a strong reaction against this perspective. Critics call into question the very existence of electoral strongholds, as well as candidates' ability to maintain them and interest in so doing. They also seek to show that parties play an important electoral role, despite the incentives towards personalism inherent in the system.

\section{Competition and reelection}

The systematic examination of the relationship between electoral competition and congressional reelection has a long history. The emergence and development of a debate on the subject are largely confined to the North American context. An inverse correlation exists between incumbents' electoral advantages and electoral competition (ABRAMOWITZ, 1991; ABRAMOWITZ et al., 2006; FEREJONH, 1977; GLAZER, BERNARD and ROBBINS, 1987; LYONS and GALDERISI, 1995; MAYHEW, 1974; TUFTE, 1973). According to Mayhew (1974), the electoral advantage enjoyed by incumbents is the main cause of reduced competition in the US House of Representatives. Likewise, Tufte (1973) believes that pro-incumbent bias in redistricting is a key variable in explaining this reduction. Lyons and Galderisi (1995) and Abramowitz et al. (2006) show that incumbents' attributes and party polarization have a negative and significant effect on electoral competition.

Doubts exist about the mechanisms linking electoral competition to congressional reelection. The specialized literature usually considers the 
relationship between three variables: 01 . the swing ratio ${ }^{4} ; 02$. electoral competition; and 03. votes for incumbents. In general, these works identify a strong and significant correlation between the swing ratio, competition, and the electoral performances of incumbents. A reduced swing ratio is usually associated with reduced competition, and strengthened incumbents. Three explanations are constructed from this scenario. In the first, the main culprit is redistricting. In this scenario, incumbents benefit from a process that implies reduces both swing ratio and electoral competition (LYONS and GALDERISI, 1995; TUFTE, 1973).

However, there are those who cite incumbents' attributes as an independent variable with a causal role in the process (ABRAMOWITZ, 1991; ABRAMOWITZ et al., 2006; CAMPBELL and JUREK, 2003; COX and KATZ, 1996, 2004; KAZEE, 1983; MAYHEW, 1974). According to this point of view, the resources available to an incumbent, as well as his/her capacity to see off challengers are the key variables, and are responsible for such success as an incumbent may enjoy, as well as any reduction in the swing ratio and/or electoral competition. Finally, there is a strain of thought that postulates a moderate causal relationship between swing ratio, electoral competition, and votes for incumbents (BLACK and BLACK, 2002; JACOBSON, 2007; STONECASH, 2003, 2008; STONECASH, BREWER and MARIANI, 2003). In this last scenario, a deepening of electoral cleavages is the main cause of the entire process. The growth of incumbent advantage reflects a secular, partisan realignment of the electorate (KEY, 1959) ${ }^{5}$. The argument is that over the last fifty years, the configuration of Republican and Democrat electorates has changed significantly, especially in geographic and ethnic terms (BLACK and BLACK, 2002; POLSBY, 2004; SINCLAIR, 1982). According to Stonecash (2007), this movement is responsible for what has been interpreted as increased incumbent advantage. The debate remains a live one, with no clear victor thus far.

\footnotetext{
${ }^{4}$ The rate corresponds to the fluctuation in the number of seats obtained by a party given the percentage of votes it receives.

${ }^{5}$ In the literature, there is a difference between critical and secular realignment. The first focuses on an abrupt change in the constituency of supporters of one of the parties. The second corresponds to a relative shift in these groups, particularly in cases of party hopping.
} 
To our knowledge, few Brazilian studies on electoral competition have considered reelection as an independent variable ${ }^{6}$. The impact of incumbent advantage on electoral competition remains unknown. If such an advantage does exist, little is known about its effect. In general, works on this topic examine or explain the geography of votes for incumbents. Silva (2013) questions the existence of electoral strongholds in Brazil. For him, the absence of high levels of imbalance makes competition part and parcel of elections. He later (2017) points out that part of the concentration of votes for congressional candidates can be put down to district magnitude. In turn, Avelino, Biderman and Barone (2012) find that the election of an mayor increases his/her party vote in proportional representation elections. They show that parties coordinate elections at municipality, state and federal levels in order to improve their performance. Borges, Paula and Silva (2016) demonstrate the effect of government-opposition cleavage on vote geography in congressional elections. They show that voting patterns for opportunist candidates present higher levels of fragmentation and dominance. Directly or indirectly, these works assume a relationship between electoral competition and reelection campaigns. The focus falls either on the geography of incumbent votes or on municipal-level electoral competition.

There are also studies of the opposite relationship, i.e. on the effect of competition on reelection. According to Ames (1995), the vulnerability of candidates for reelection presents a positive correlation with competition. The main reason for this is the absence of an electoral list that would prevents intra-party competition, especially among incumbents themselves (AMES, 1995). For Samuels (2000), the nature of electoral competition in Brazil conspires against incumbents. Disadvantages are faced both in the selection of candidates (direct competition with strong candidates) and in the electoral process (all starting from the same position on the list). Similarly, Santos (2003) believes that electoral competition is an important variable for explaining both a decision to stand for reelection, and

6We can cite the following: Ames (1995, 2003); Avelino, Biderman and Barone (2012); Borges, Paula e Silva (2016); Braga (2006); Campello and Zucco (2008); Carneiro and Almeida (2008); Kinzo, Martins and Borin (2004); Limongi (2006); Nicolau (2006) and, Silva (2013). 
incumbents' electoral success or failure. For Pereira and Rennó (2001), however, electoral competition should not be considered as a variable that can explain reelection ${ }^{7}$. This is because the competition is endogenous to a model that considers only party presence, projects and pork ${ }^{8}$. In following works, Pereira and Rennó (2007) show that electoral competition does not have a significant effect on congressional reelection, contrary to their expectation that it would ${ }^{9}$.

In short, there is an international tradition that systematically investigates the relationship between electoral competition and congressional reelection. The literature seeks to identify not only the effects, but also the mechanisms that give rise to this phenomenon. Redistricting, candidate attributes, and electoral behavior are some of the factors cited. In Brazil, most studies cite electoral competition as an explanatory variable for incumbent reelection. The general view is that competition has a significant and negative effect on reelection. A systematic analysis on the relationship between the number and distribution of incumbents in an election, and electoral competition remains to be undertaken.

\section{Methodology}

In this section, we present our research strategy. Our main goal was to estimate the effect of congressional reelection campaigns on electoral competition. To do so, we had to establish: 01 . what our main hypothesis was and how we formulated it; 02 . how we measured incumbent competition (VD) and electoral performance (VI); 03. what the control variables were; and 04. what techniques were to be used in our research. Table 01 summarizes our methodology step-by-step.

\footnotetext{
${ }^{7}$ Competition, for Pereira and Rennó (2001), corresponds to the 'competition variable' which represents the difference between the sum of votes obtained by the candidate where he/she obtained the most votes, and the total votes of the other candidate with the most votes in the same municipality.

${ }^{8}$ Pereira and Rennó (2001) show endogeneity by measuring the impact of the variables of party presence, projects and pork in electoral competition.

9In this work, electoral competition is measured by the number of candidates competing for votes in a state assembly election.
} 
Our main hypothesis is that 'attempts at congressional reelection have significant and negative effects on electoral competition'. According to the literature, the Brazilian electoral system favors personalism. In other words, it favors an electoral focus on individual candidates. In general, incumbents take advantage of this dynamic by their greater prominence (in terms of resources and name recognition) vis-à-vis challengers. Therefore, personalism is the mechanism linking congressional reelection with electoral competition. Our assumption is that personalism produces a positive, pro-incumbent effect that in turn causes imbalance in the competition.

Table 01. Summary of methodology

\begin{tabular}{|c|c|c|}
\hline Stage & Elements & Description \\
\hline \multirow[t]{4}{*}{ Descriptive } & Unit of Analysis & 26 States + Federal District \\
\hline & Period & $1990-2014$ \\
\hline & Variables & $\begin{array}{l}\text { Vote imbalance, vote concentration, concentration of } \\
\text { incumbents, proportion of incumbents. }\end{array}$ \\
\hline & Techniques & Descriptive statistics and time series models \\
\hline \multirow[t]{4}{*}{ Inferential } & Unit of Analysis & 26 States + Federal District \\
\hline & Period & $2002-2014^{* *}$ \\
\hline & Variables* & $\begin{array}{l}\text { VD = vote concentration; VI = incumbent concentration; } \\
\text { proportion of incumbents; VC = state electorate; magnitude; } \\
\text { imbalance; GDP per capita, region, percentage of incumbents } \\
\text { in coalition; revenue concentration; proportion of small } \\
\text { municipalities; percentage of candidates from the parties of } \\
\text { the elected governor. }\end{array}$ \\
\hline & Techniques & $\begin{array}{l}\text { Ordinary least square (OLS) regression with panel data and } \\
\text { weighted least square regression with panel data }\end{array}$ \\
\hline
\end{tabular}

Source: Prepared by the authors based on Research Design.

Notes: ${ }^{*} \mathrm{VD}=$ dependent variable; $\mathrm{VI}=$ independent variable; $\mathrm{VC}=$ control variable ${ }^{*}$ Reduction of period by data availability.

\section{VD: electoral competition}

There is a lively debate over the most appropriate measure for electoral competition (AVELINO, BIDERMAN and BARONE, 2012; AVELINO, BIDERMAN and SILVA, 2016; CARAMANI, 2003; HOLBROOK and VON DUNK, 1993). According to Taagepera and Ray (1977), there are many indexes whose goal is to measure "the degree to which components of an entity vary in number and differ from one another in size" (TAAGEPERA and RAY, 1997, p. 275). Where competition is present, party fragmentation has been the most frequently observed dimension 
(GOLOSOV, 2010; NICOLAU, 2006; PEIXOTO and GOULART, 2014). In this text, we 'define electoral competition as the level of dispute between the candidates or parties for votes'. We followed the suggestion of Caramani (2003) and Silva (2013) and considered both vote fragmentation and the degree of balance among competitors as measures of competition. To do this, we looked at two measures suggested by Taagepera (1979), namely, o 'Imbalance Index' (T) and the 'Concentration Index' (HH). The goal is to obtain a more complete picture of the competitiveness of elections ${ }^{10}$. The formulae follow:

$$
\mathrm{HH}=\sum_{i=1}^{\infty} P_{i}^{2} \quad \mathrm{~T}=\frac{\sum_{i=1}^{\infty} \frac{\left(P_{i}-P_{i+1}\right)}{i}-H H^{2}}{\sqrt{H H}-H H^{2}}
$$

Where:

$P=$ total size of entity;

$P_{i}=$ size of $i$-th component;

$i=$ rank of component in descending order;

$P_{i}=$ proportion of $i$-th component $\left(P_{i} / P\right)$.

We have represented electoral competition through the imbalance between competitors (T) and the pattern of vote distribution among them $(\mathrm{HH})$. The most competitive disputes present lower levels of imbalance and vote concentration. Each state in each election will have a level of competition based on these two measures.

\section{The presence of incumbents}

We gauged reelection using two measures: 01 . concentration of candidates for reelection in parties/coalitions and 02. proportion of these candidates in an election. Like the concentration of votes, the degree of concentration of incumbents was determined using the Herfindahl-Hirschmam index (HH).

\footnotetext{
${ }^{10} \mathrm{An}$ anonymous reviewer gave us the suggestion of specifying competitions. The idea is to restrict the calculation to a specific set of candidates - for example, only the ones that are elected. Another idea was to measure competition using a summary measure of candidate voting. We decided not to accept the suggestions for two main reasons: 01. any candidate classification criteria seemed arbitrary to us and 02 . summary measures imply a reduction in the variance of the phenomenon. In our view, the suggestions would bring biases that would methodologically weaken the analyses.
} 
Nominally, the concentration will correspond to the sum of the square of the proportion between the candidates for reelection of each party/coalition, the total sum representing the candidates for reelection in each state in each election. The proportion of incumbents is calculated from the total number of candidates in each state in each election. The concentration and percentage of incumbents are our independent variables. Our hypothesis is that both the concentration and the percentage have negative and significant effects on electoral competition. We have assumed that incumbents enjoy the advantage in the race and, therefore, subvert competition. Therefore, in a scenario where the incumbents are many and concentrated, competition tends to be reduced. However, there is a risk of concentration increasing internal competition, but we think it reasonable to think: 01. that de-concentration of incumbents by party/coalition generates even greater competition and 02 . that political parties are able to coordinate campaigns very closely to avoid conflicts between their incumbent candidates.

\section{VC: control}

To bolster the reliability of our results we have added a set of control variables. Our goal is to engage in dialog with previous work and eliminate competing causes. First, we added to our model some of the variables cited by Ames (2003) and Silva (2013): 01. state electorate; 02. magnitude; 03. imbalance; 04. GDP per capita; and 05. region. Additionally, we controlled for: 06. campaign revenue from its concentration level $(\mathrm{HH})$; 07. proportion of small municipalities; 08. percentage of coalition incumbents; and 09. percentage of incumbents from the governor-elect's party ${ }^{11}$. The inclusion of revenue is due to the widely documented finding of its effect on voting (ABRAMOWITZ, 1991; JACOBSON, 1978, 1989, 1992; LEMOS, MARCELINO and PEDERIVA, 2010; PEREIRA and RENNÓ, 2001, 2007; SAMUELS, 2001). The control variable of the number of small municipalities is due to references in the literature to 'grotões' (AMES, 2003). Finally, the inclusion of the percentage of incumbents from the coalition and of the governor-elect's party is an attempt to control for the dependency of the candidates on other actors

\footnotetext{
${ }^{11}$ We would like to thank an anonymous reviewer for the idea of including the last three variables.
} 
in the political system (ABRÚCIO and SAMUELS, 1997; AMES, 2003; SAMUELS, $2001)^{12}$.

\section{Techniques}

We used descriptive and inferential statistics to analyze the data. In the descriptive statistics, we presented the main measures of central tendency and the time series of the dependent and independent variables in our research design. The inferential component is performed from a regression analysis of panel data. In this way, we intend to measure the effects that cannot be observed in pure transverse cutting or by a simple time series. The objective is to identify the effect of reelection attempts on electoral competition and to make sure that they exist throughout the observed time series.

\section{Results}

To begin the descriptive step, we present some measures of central tendency and electoral competition variance. More specifically, we present the measures of the imbalance and concentration of the votes for the candidates for federal congress in the 26 Brazilian states plus the Federal District. In addition, we analyzed the averages of the two variables during the period of redemocratization ${ }^{13}$.

The imbalance average exceeds the concentration average by 0.128 points (79.01\%). However, the concentration has a larger variation $(+12.48 \%)$. In addition, the tests indicate the absence of a deterministic (KPPS $=0.199$ and 0.298 $\mathrm{p}>0.100$ ) or random (KPPS $*=0.047$ and $0.135 \mathrm{p}>0.05$ ) trend in the time series of the two measures. The Graph 01 also reports the estimation of a future point based on a series lag. The model with this configuration is best suited to predict the behavior of the average of imbalance. In other words, the immediate past of the

\footnotetext{
${ }^{12} \mathrm{At}$ the suggestion of an anonymous reviewer, we report that for the calculation of the incumbent percentages from the coalition and party of the governor-elect, we used the total number of candidates in the dispute as the denominator. Coalition here refers to national-level coalitions.

${ }^{13}$ All analyses were performed using 'Gretl' (Gnu Regression, Econometrics and Time-series Library) open source software.
} 
imbalance predicts its future better than the immediate past of the concentration. Therefore, it can be said that the behavior of the imbalance series is more regular.

The next step is to analyze the descriptive statistics of the independent variables. In the Tables 02 and 03 and Graph 02 there are some information about electoral competition and vote imbalance by election. Table 04 presents some of the main measures of central tendency and proportion and concentration variants of incumbents in the cases analyzed. The Graphs 03 and 04 and Table 04 present data on the time series of these two measures.

The concentration of incumbents in coalitions varies more than the proportion of candidates with this status $(+47.64 \%)$. The time series of both measures show no random (KPPS $=0.184 \mathrm{p}>0.100 / \mathrm{KPPS} *=0.267 \mathrm{p}>0.100)$ or deterministic (KPPS $=0.017 \mathrm{p}>0.100 /$ KPPS $*=0.125 \mathrm{p}>0.100)$ trends. Fitting the model with a lag is best for predicting concentration values (Adjusted $R^{2}=$ 0.025, more details in the Table 05). However, even for this measure, only $2.5 \%$ of the variation in values can be explained by its immediate past. This means that the past is not a good predictor for the future of both measures, or that the series do not exhibit regular behavior.

Table 02. Electoral competition

\begin{tabular}{lclllll}
\multicolumn{1}{c}{ Indexes } & $\mathrm{N}$ & Minimum & Maximum & Average & Deviation & $\mathrm{CV}$ \\
\hline Imbalance & 189 & 0.012 & 0.601 & 0.162 & 0.121 & 74.69 \\
Concentration & 189 & 0.004 & 0.416 & 0.039 & 0.034 & 87.17 \\
\hline
\end{tabular}

Source: Prepared by the authors based on Superior Electoral Court.

Graph 01. Vote imbalance by election

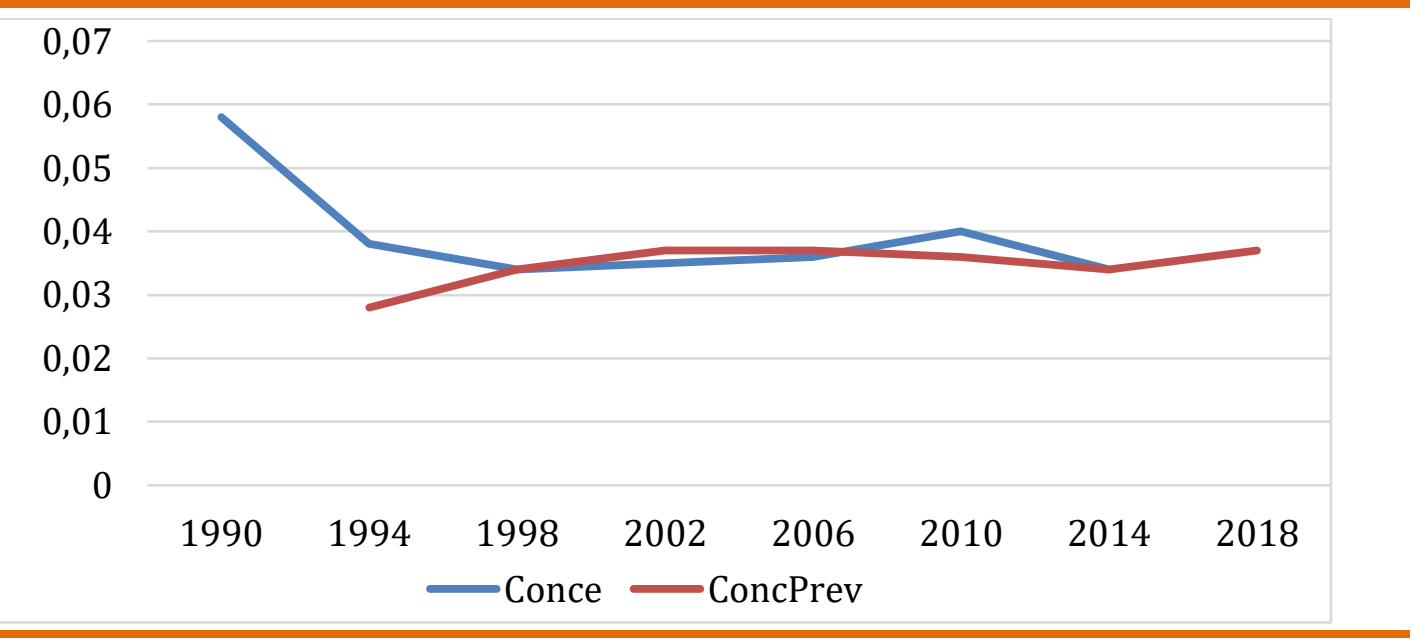

Source: Prepared by the authors based on Superior Electoral Court. 
Graph 02. Concentration of vote by election

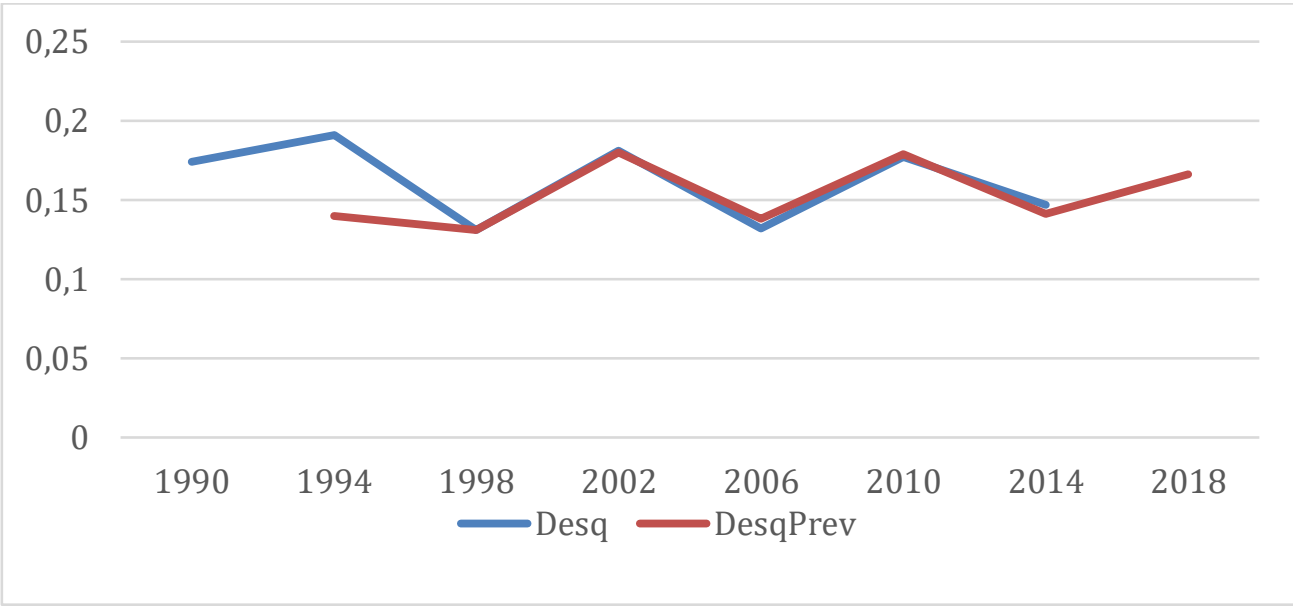

Source: Prepared by the authors based on TSE.

Table 03. Time series regression models (Stationarity and fit test)

\begin{tabular}{|c|c|c|c|c|}
\hline \multirow[t]{2}{*}{ Tests/Measures } & \multicolumn{2}{|c|}{ Imbalance } & \multicolumn{2}{|c|}{ Concentration } \\
\hline & Values & $P$ value & Values & $P$ value \\
\hline KPSS & 0.119 & $>0.100$ & 0.298 & $>0.100$ \\
\hline KPSS* & 0.047 & $>0.100$ & 0.135 & $>0.05$ \\
\hline $\mathrm{R}^{2}$ Adjusted & 0.957 & - & 0.245 & - \\
\hline $\mathrm{F}$ & 99.554 & 0.002 & 0.471 & 0.543 \\
\hline SQR & 0.000 & - & 0.000 & - \\
\hline
\end{tabular}

Source: Prepared by the authors based on Superior Electoral Court.

Notes: *KPSS including deterministic bias.

Graph 03. Average incumbent concentration

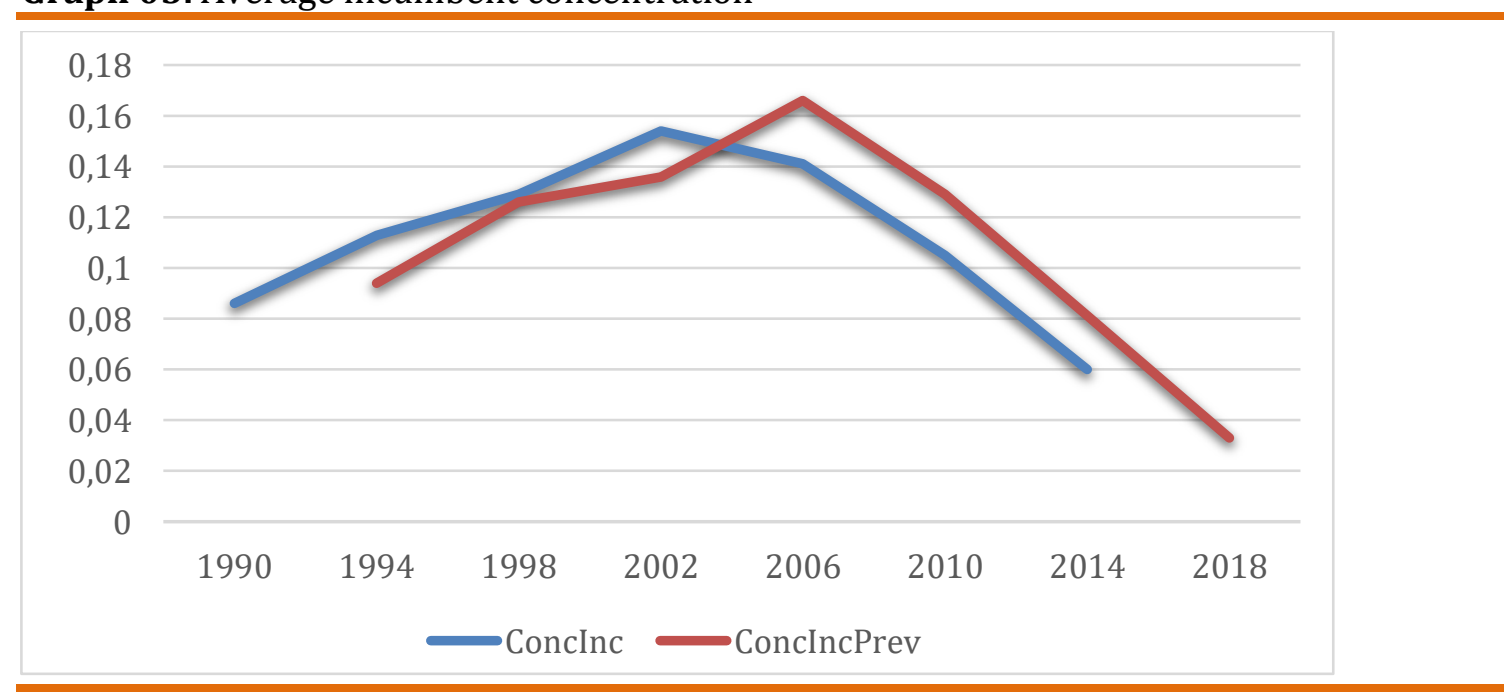

Source: Prepared by the authors based on Superior Electoral Court. 
Graph 04. Average incumbent proportion

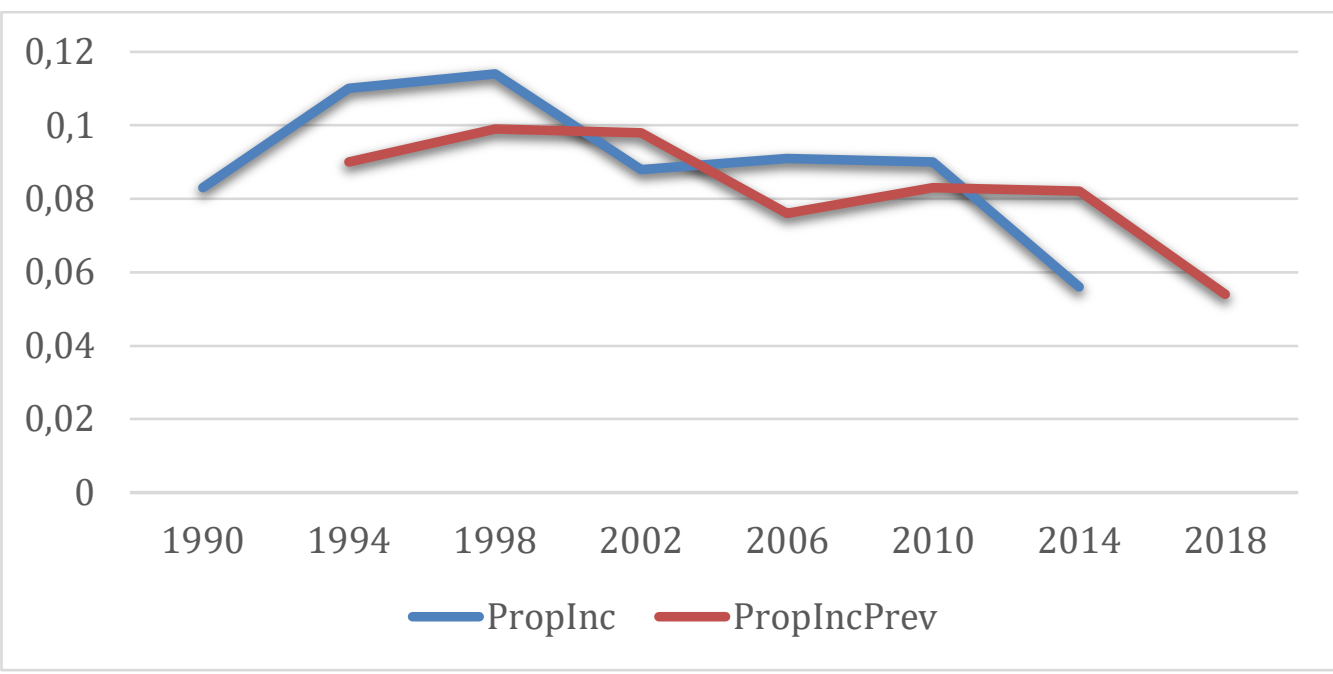

Source: Prepared by the authors based on Superior Electoral Court.

Table 04. Reelection attempt

\begin{tabular}{lclllll}
\hline \multicolumn{1}{c}{ Measures } & $\mathrm{N}$ & Minimum & Maximum & Average & Deviation & CV \\
\hline Proportion & 189 & 0.000 & 0.262 & 0.087 & 0.037 & 42.53 \\
Concentration & 189 & 0.000 & 0.879 & 0.112 & 0.101 & 90.17 \\
\hline
\end{tabular}

Source: Prepared by the authors based on Superior Electoral Court.

Table 05. Time series regression models (Stationarity and fit test)

\begin{tabular}{lllll} 
Tests/Measures & \multicolumn{2}{c}{ Concentration } & \multicolumn{2}{c}{ Proportion } \\
\cline { 2 - 5 } & \multicolumn{1}{c}{ Values } & \multicolumn{1}{c}{ P value } & Values & \multicolumn{1}{c}{ P value } \\
\hline KPSS & 0.184 & $>0.100$ & 0.295 & $>0.100$ \\
KPSS* & 0.017 & $>0.100$ & 0.135 & $>0.05$ \\
R $^{2}$ Adjusted & 0.025 & - & 0.023 & - \\
F & 0.025 & 0.884 & 0.543 & 0.516 \\
SQR & 0.295 & - & 0.001 & - \\
\hline
\end{tabular}

Source: Prepared by the authors based on Superior Electoral Court.

Notes: *KPSS including deterministic bias.

Overall, the analyses performed show the absence of random and/or deterministic trends in the dependent and independent variables. In other words, both the imbalance series and the vote concentration are stationary, as are the time series of concentration and proportion of incumbents. However, the immediate past reflects imbalance better than vote concentration. Both measures vary by state. The precision of the regression model with a lag to predict the variation of 
the concentration average is low. To predict the variation in concentration and proportion of incumbents, the fit of the models is even lower. Therefore, the series of these variables are stationary but not very regular. The analysis by federal unit presents some variation in this diagnosis (more details in Tables S01 and S02 in the annexes). For example, in the Federal District, $15 \%$ (Adjusted $R^{2}=0.152$ ) of the variance of incumbent concentration in coalitions can be explained by its immediate past.

\section{Dependent variable}

After this descriptive analysis, the next step is to try to answer the main question of our text: what is the effect of the reelection attempts on electoral competition? For the sake of simplification, we should first investigate which variable is most appropriate for estimation. Thus far, we have worked with two measures: imbalance and concentration of candidate voting in the states. Theoretically, both measures are suitable for measuring competition. However, it is necessary to verify the assumption of normality, which is fundamental to the models we intend to estimate. The Graphs 05 and 06 and Table 06 helped us in this task.

The concentration density curve is closer to normal. More specifically, the result of the Kolvogorov-Smirnov test does not allow us to reject the null hypothesis of normal distribution of the variable (KS = $0.063 \mathrm{p}=0.200$ ) in the case of concentration only. The same can be said for the chi-square test $\left(X^{2}=3.033 \mathrm{p}=0.219\right) 14$. Therefore, concentration is best suited to an Ordinary Least Squares (OLS) model. Thus, our analysis continues by using concentration as a measure of electoral competition, but we include models estimated with the natural log of imbalance in the annexes (Table S03) ${ }^{15}$.

\footnotetext{
${ }^{14}$ Part of this result is due to the weight of specific cases in the calculation of measures. Both consider all candidates from each state, but the imbalance is the most affected by the case that represents the largest proportion of votes obtained (> Pi). The annex contains a comparison of the average of the averages calculated with and without this case. For more details see Graphs S01 and $\mathrm{S} 02$ in the annexes.

${ }^{15}$ We would like to thank an anonymous reviewer for suggesting we report this analysis.
} 
Graph 05. Density curve of vote concentration

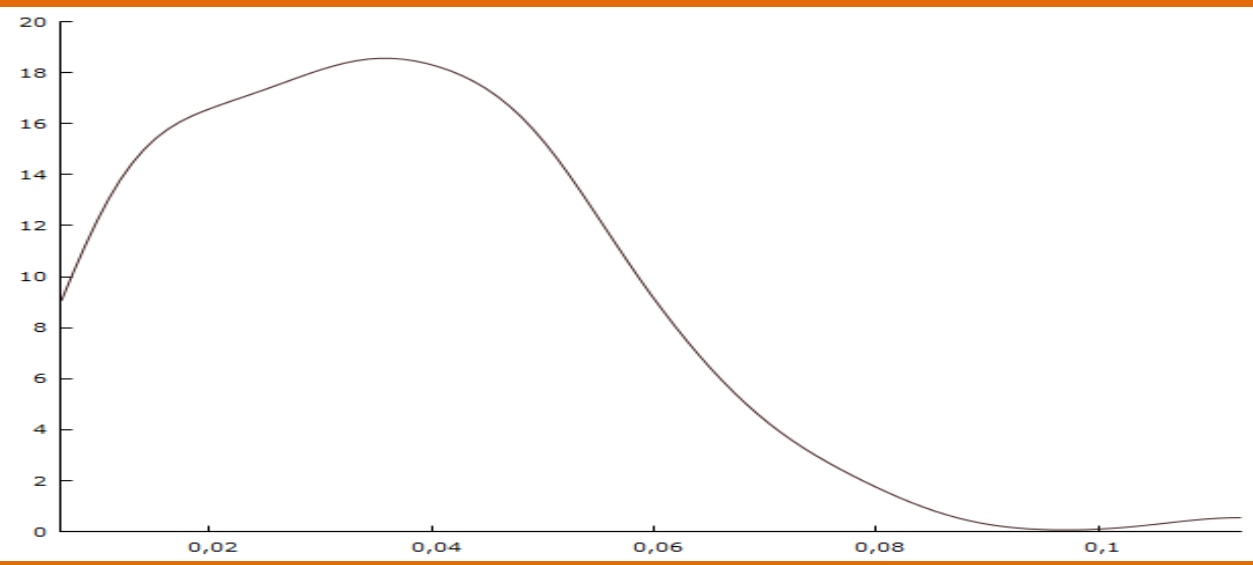

Source: Prepared by the authors based on Superior Electoral Court.

Graph 06. Density curve of vote imbalance

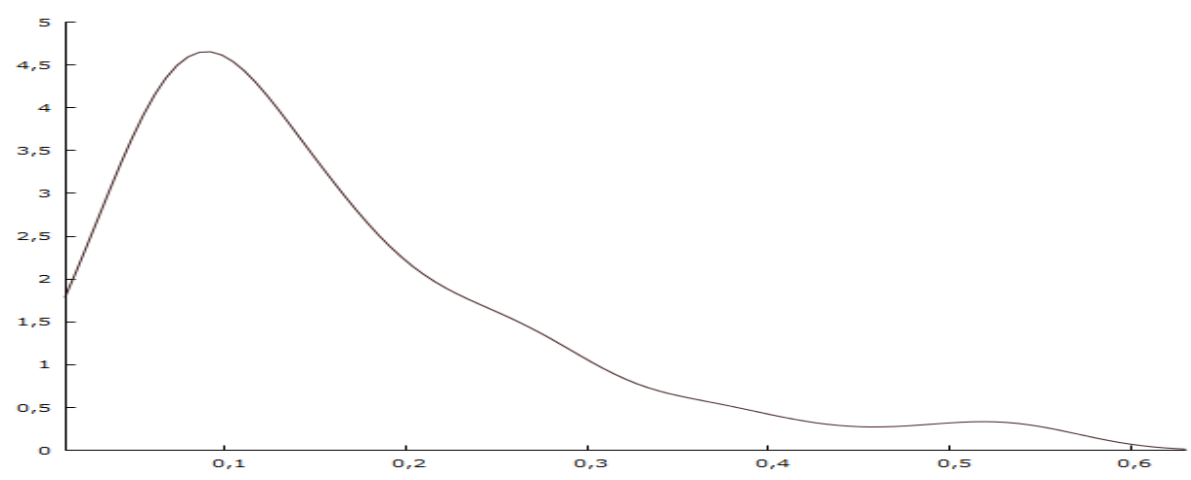

Source: Prepared by the authors based on Superior Electoral Court.

Table 06. Measures and tests of normality

\begin{tabular}{|c|c|c|c|c|}
\hline \multirow{2}{*}{ Tests/Measures } & \multicolumn{2}{|c|}{ Imbalance } & \multicolumn{2}{|c|}{ Concentration } \\
\hline & Values & $P$ value & Values & P value \\
\hline Kolmogorov-Smirnov & 0.152 & 0.000 & 0.063 & 0.200 \\
\hline Chi-squared & 45.709 & 0.000 & 3.033 & 0.219 \\
\hline
\end{tabular}

Source: Prepared by the authors based on Superior Electoral Court.

\section{Models}

The theoretical discussion shows that Brazilian literature prefers to treat electoral competition as an explanatory variable for congressional reelection. Therefore, there has been no systematic analysis of the effect of attempted reelection on electoral competition. This is despite the unquestionable variation in competition and incumbent electoral performance with each election in each 
state. So, do elections become less competitive when more incumbents decide not to run for reelection? To the best of our knowledge, this question remains unanswerable. Therefore, our model tries to estimate this effect. In Brazil, the ability of incumbents to maintain/expand their constituencies is unclear. A sizeable part of the literature argues that incumbency is worth little, as it is not easy to achieve recognition from the electorate for benefits provided. We have restricted our analysis for the period 2002-2014 for data availability reasons. The results are reported in the Table 07.

The fixed effects model (1) identifies the concentration of revenue and the percentage of incumbents in the coalition as the only significant explanatory variables ${ }^{16}$. Both revenue concentration and the percentage of incumbents in the coalition reduce competition. Therefore, the model points to incumbent advantage. However, a set of test statistics highlights problems with model specification (1). The main challenge lies in possible variation of the constant and effect of some variables among Brazilian states ${ }^{17}$. Model (2) helps investigate this suspicion by assuming random effects. The main changes are the inclusion of electorate size and temporal dummies in the statistically significant set of variables. The electorate has a negative effect, that is, larger states tend to have more contested elections on average. Temporal variables suggest that the most popular dispute was the first in the series analyzed (2002-2014). However, the divergence between models (1) and (2) results increases suspicions about the inadequacy of OLS models for estimating the effects (Table 07) ${ }^{18}$. One way to increase the robustness of the estimate is to weigh the observations ${ }^{19}$.

\footnotetext{
${ }^{16}$ Model (1) has fixed effects for transverse and temporal observations. Therefore, it controls the unobserved variables that are constant over time and between states.

${ }^{17}$ The Wald test tests for temporal dummies significance and error heteroskedasticity. The F test tests for intercept variance between transverse unit report inadequacy and reliability problems concerning the parameters estimated by the model.

${ }^{18}$ According to the literature, when there are divergences between the fixed and random effect models in terms of statistical significance of the estimators, the first one should be relied on (GREENE, 2008; GUJARATI and PORTER, 2011; STOCK and WATSON, 2004).

${ }^{19} \mathrm{As}$ seen, the fixed effect model presents the residual heteroskedasticity problem $(\mathrm{F}=9925.88 \mathrm{p}$ $<0.05$ ). Therefore it violates the assumption of constant variance of residues (GREENE, 2008; GUJARATI and PORTER, 2011; STOCK and WATSON, 2004). In Graphs S03 and S04 there is a comparison between the distribution of residues by transverse groups. Clearly, the WLS model reduces the variance of residues in most states.
} 
Table 07. Estimates of parameters from panel model

\begin{tabular}{|c|c|c|c|c|}
\hline & $(1)^{\mathrm{a}}$ & (2) & (3) & (4) \\
\hline \multirow[t]{2}{*}{ Const } & -0.0226 & $0.0206^{* * *}$ & $0.0172^{* * *}$ & $0.0261^{* * *}$ \\
\hline & $(0.0261)$ & $(0.0049)$ & $(0.0029)$ & $(0.0050)$ \\
\hline \multirow[t]{2}{*}{ Incumbent Concentration } & $-3.2315 e-05$ & -0.0024 & $-0.0126^{* *}$ & $-0.0181^{* *}$ \\
\hline & $(0.0083)$ & $(0.0089)$ & $(0.0061)$ & $(0.0072)$ \\
\hline \multirow{2}{*}{ Percentage Incumbents ${ }^{20}$} & 0.0001 & -0.0003 & $-0.0004^{*}$ & $-0.0010^{* *}$ \\
\hline & $(0.0003)$ & $(0.0003)$ & $(0.0002)$ & $(0.0004)$ \\
\hline \multirow[t]{2}{*}{ Revenue Concentration } & $0.0623^{* * *}$ & $0.0950^{* * *}$ & $0.1561^{* * *}$ & 0.0928 \\
\hline & $(0.0215)$ & $(0.0218)$ & $(0.0181)$ & $(0.0613)$ \\
\hline \multirow[t]{2}{*}{ Electorate } & $5.0993 \mathrm{e}-010$ & $-2.3966 \mathrm{e}-09 * * *$ & $-4.2533 \mathrm{e}-09 * *$ & $-3.9556 \mathrm{e}-09 * * *$ \\
\hline & $(2.4016 \mathrm{e}-09)$ & $(8.8850 \mathrm{e}-010)$ & $(1.0457 \mathrm{e}-09)$ & $(1.0930 \mathrm{e}-09)$ \\
\hline \multirow{2}{*}{ GDP per capita } & 0.0005 & -0.0003 & $-0.0004^{* * *}$ & $-0.0004^{* * *}$ \\
\hline & $(0.0009)$ & $(0.0002)$ & $(0.0001)$ & $(0.0001)$ \\
\hline \multirow[t]{2}{*}{ Imbalance } & $0.0001^{*}$ & $4.8286 \mathrm{e}-05^{*}$ & $0.0001^{* * *}$ & $0.0001^{* * *}$ \\
\hline & $(9.0389 \mathrm{e}-05)$ & $(2.7745 \mathrm{e}-05)$ & $(3.2998 \mathrm{e}-05)$ & $(3.4763 e-05)$ \\
\hline Percentage Small & 0.0001 & $8.8693 e-05$ & $7.8569 \mathrm{e}-05^{* * *}$ & $7.5315 \mathrm{e}-05^{* * *}$ \\
\hline Municipalities & $(0.0001)$ & $(6.0501 \mathrm{e}-05)$ & $(2.1501 \mathrm{e}-05)$ & $(2.2864 \mathrm{e}-05)$ \\
\hline Percentage of Incumbents & $0.0007^{* *}$ & $0.0008^{* *}$ & $0.0009^{* * *}$ & $3.01243 \mathrm{e}-05$ \\
\hline from Coalition & $(0.0003)$ & $(0.0003)$ & $(0.0003)$ & $(0.0004)$ \\
\hline Percentage of Candidates & 0.0001 & $7.2638 \mathrm{e}-05$ & $6.7467 e-05$ & $3.3894 \mathrm{e}-05$ \\
\hline from Governor's Party & $(0.0001)$ & $(0.0001)$ & $(0.0001)$ & $(0.0001)$ \\
\hline Percentage of Big Party & 0.0001 & $6.6383 e-05$ & $6.4343 \mathrm{e}-05^{*}$ & $6.6918 \mathrm{e}-05^{*}$ \\
\hline Candidates & $(6.8247 e-05)$ & $(6.1456 \mathrm{e}-05)$ & $(3.3750 \mathrm{e}-05)$ & $(3.5313 e-05)$ \\
\hline Percentage of Incumbents & 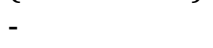 & - & - & 0.0066 \\
\hline * Concentration Income & - & - & - & $(0.0058)$ \\
\hline Percentage of Incumbents & - & - & - & $6.9606 \mathrm{e}-05^{* *}$ \\
\hline *Incumbents from & - & - & - & $(3.4129 e-05)$ \\
\hline \multicolumn{5}{|l|}{ Coalition } \\
\hline \multirow[t]{2}{*}{ Dummy 2006} & 0.0029 & $0.0049^{* * *}$ & $0.0048^{* * *}$ & $0.0041^{* * *}$ \\
\hline & $(0.0016)$ & $(0.0016)$ & $(0.0013)$ & $(0.0014)$ \\
\hline \multirow[t]{2}{*}{ Dummy 2010} & 0.0056 & $0.0088^{* * *}$ & $0.0105^{* * *}$ & $0.0094^{* * *}$ \\
\hline & $(0.0020)$ & $(0.0022)$ & $(0.0020)$ & $(0.0020)$ \\
\hline \multirow[t]{2}{*}{ Dummy 2014} & 0.0056 & $0.0046^{* * *}$ & $0.0038^{* * *}$ & $0.0026^{*}$ \\
\hline & $(0.0036)$ & $(0.0017)$ & $(0.0013)$ & $(0.0014)$ \\
\hline SQR & 0.0012 & 0.0064 & 84.35340 & 85.4526 \\
\hline $\mathrm{R}^{221}$ & 0.9305 & - & 0.864501 & 0.8515 \\
\hline $\mathrm{R}^{2}$ Inside & 0.4344 & - & 0.844929 & 0.8262 \\
\hline $\mathrm{F}$ & $22.9293^{* * *}$ & - & $44.170^{* * *}$ & $33.6448^{* * *}$ \\
\hline $\mathrm{Fb}^{\mathrm{b}}$ & $6.077^{* * *}$ & - & & \\
\hline Likelihood Log & 443.1036 & 356.5304 & -136.6821 & -137.3553 \\
\hline Wald Heterosk. & $99925.88^{* *}$ & - & - & - \\
\hline Wald Time & 2.6948 & $15.9872^{* * *}$ & & \\
\hline Breusch-Pagan & - & $39.1075^{* * *}$ & - & - \\
\hline Hausman & - & $48.2803^{* * *}$ & - & - \\
\hline
\end{tabular}

Source: Prepared by the authors based on Superior Electoral Court.

Notes: Observations: 108 Number of Groups: 26.

$* \mathrm{p}<0.10^{* *} \mathrm{p}<0.05^{* * *} \mathrm{p}<0.001$

Model: a Magnitude and region variables omitted by exact collinearity; ${ }^{\mathrm{b}}$ Test $\mathrm{F}$ for differentiation of intercept

${ }^{20}$ To standardize the results, we decided to analyze the percentage rather than the proportion, a difference restricted to the scale.

${ }^{21}$ In this paper, we have opted not to engage in a deeper discussion about the explanatory capacity of the variables. The reason for this is the focus on the direction and magnitude of the concentration effect and the percentage of incumbents. 
In other words, to estimate a model that gives greater importance to the group of observations that are closer to the average, and less relevant to the others ${ }^{22}$. In this Weighted Least Squares (WLS) model (3), the following variables are statistically significant: 01 . incumbent concentration; 02 . concentration of revenue; 03. electorate; 04. GDP per capita; 05 . percentage of small municipalities; 06. percentage of coalition incumbents; and 07. dummies (2006; 2010 and 2014). The main finding of this model is the negative effect of incumbent concentration. Contrary to what we had expected, the greater the concentration of candidates for reelection in parties/coalitions, the greater the electoral competition in an election. Each extra point in the incumbent concentration reduces the concentration of votes by 0.0126 , thus increasing electoral competition ${ }^{23}$. It seems that the grouping of incumbents intensifies competition. The absence of any statistical significance for the percentage of incumbents reinforces the weight of concentration/grouping in parties/coalitions. This finding reinforces the literature on vote personalism in Brazil and the possible effect on the absence of a closed list in legislative elections (AMES, 2003; NICOLAU, 2006). This is especially true if we observe that the percentage of large party candidates is not statistically significant. However, these findings bring us closer to the literature opposed to the existence of so-called 'grotões' (AVELINO, BIDERMAN and BARONE, 2012; AVELINO, BIDERMAN and SILVA, 2016; SILVA, 2017), seeing as it is incumbents that would be responsible for the creation of these redoubts ${ }^{24}$. In addition to this central result, the variables of revenue concentration, percentage of incumbents in the coalition, and candidates from the governor-elect's party are noteworthy for their behavior - the first two by the constant presence of statistical

\footnotetext{
${ }^{22}$ Explaining the evolution of models matters for readers to evaluate estimation methods. Theoretically, knowing that the OLS residuals are heteroskedastic, the reader understands that the variables have different predictive effects for each federal unit. This way you can identify, for example, in which one the OLS behaves best. The Graphs S03 and S04 ilustrate the heteroskedastic residuals in the two models.

${ }^{23}$ It is worth pointing out that the competition average (vote concentration) for the series (20022014 ) is 0.026 with standard deviation of 0.013 .

${ }^{24}$ The estimated effect of the percentage of small municipalities puts this argument in check. In WLS models, this variable has a positive and significant effect on vote concentration, i.e. it reduces competition.
} 
significance, and the last by its absence. Up to model (3), revenue concentration has a positive and significant effect on vote concentration. In the best context (model 3), each additional point in revenue concentration increases the concentration of votes by 0.156 , thus significantly reducing electoral competition. Similarly, the percentage of coalition incumbents has a positive and significant effect on concentration. More candidates for government reelection reduce the 'heat' of the contest. In theory, this finding is an indication of the advantage enjoyed by the incumbents as described in the literature.

Our models do not seem to capture the supposed coattail effect of the governors. In none of them does the percentage of governor-elect party candidates have a significant effect on electoral competition ${ }^{25}$. Finally, we decided to subject the percentage of incumbents to one last test. Methodologically, we interacted this variable with the two most consistent effects: 01 . revenue concentration and 02 . percentage of coalition incumbents. Therefore, we assumed that revenue concentration will have a more robust effect when associated with the percentage of incumbents. Given the above results, we assumed that this interaction would have a positive and significant effect on vote concentration, meaning it would contribute significantly to reducing competition. Thus, in scenarios where the percentages of incumbents inside and outside the coalition are high, competition will be significantly reduced. We are betting on both the effect of campaign revenue and that of incumbent advantage (PEREIRA and RENNÓ, 2003, 2007; SAMUELS, 2001, 2003). We also plan to investigate the importance of coalitions more systematically (PEREIRA and MULLER, 2003; SANTOS, 2003). Model (4) presents three main results: 01. the interaction between the percentages of incumbents is positive and significant; 02. the interaction between the percentage of incumbents and the concentration of revenue is not statistically significant; and 03 . the concentration of revenue loses statistical significance. The

\footnotetext{
${ }^{25}$ We do not know how much of this result is due to the way this variable was operationalized. In fact, Borges, Paula and Silva (2016) recommend that the number of candidates in the governor's coalition be controlled as well; due to a lack of data, we cannot fully follow their suggestion. Nevertheless, we thank an anonymous reviewer for the suggestion we include this work in our bibliography.
} 
first finding reinforces the importance of participation in a coalition to electoral competition analysis. The presence of incumbents, especially from coalitions, tends to intensify competition. On the other hand, the disappearance of the statistical significance of concentration highlights the risk that this variable's effect is due to omitted variables.

\section{Final considerations}

In Brazil, the lion's share of the literature supports the view that the presence of incumbents has a negative effect on competition. Dissenters tend to restrict themselves to geographic analysis of incumbent vote, or testing for the existence of electoral strongholds. Our work investigates competition, with the independent variable being congressional reelection. Therefore, we combine a descriptive analysis, considering time series, with inferential OLS and WLS models. Our main finding contradicted our main hypothesis. In our WLS models, the concentration and percentage of incumbents had significant negative effects on vote concentration, i.e. they contributed to increased competition. We had expected that reelection attempts would unbalance the dispute by reducing competition. This is because we believed the hypothesis that personal voting tends to favor incumbents. However, we underestimate the fact that personalism is linked to the fragility of parties in organizing campaigns. Ultimately, this allows for internal competition that we had not relied on.

In the end, the main finding of this work draws attention to the weight of intra-party competition. Hitherto underestimated in Brazil, intra-party competition seems to have an effect on congressional reelection. If parties worked as teams, the most obvious effect of reelection attempts would be competition imbalance. Our results reinforce the arguments in favor of vote personalism in Brazil, especially in the absence of a closed list. Thus, it adds a caveat to works on elections that fail to take into account party organization levels.

Above all, it highlights the prevalence of candidates over parties in the electoral dispute, especially when we observe that the percentage of large party 
candidates is not statistically significant ${ }^{26}$. Our main findings also corroborate arguments against the existence of so-called 'grotões', as the incumbents themselves are supposed to be the creators of such redoubts. Overall, the findings identify competition between incumbents as having an effect on electoral competition. Future research may choose to focus exclusively on votes for these candidates, and shed more light on when, where and how these disputes occur.

In summary, our contribution to the literature focuses on two major innovations: 01. levels of analysis and 02. independent variables. Firstly, we chose to investigate competition in state elections rather than in smaller districts. The literature suggests construction of informal districts, but, in reality, elections are based on the boundaries of the states and the Federal District. Our analysis reveals that both the constant and the effect of a set of independent variables vary significantly between states. In other words, it gives evidence of the existence of electoral subsystems. Therefore, there exists a need to examine electoral results by observing variation according to federal unit.

Finally, our analysis estimates the effect of reelection on competition, controlled by other components of the electoral system. Therefore, it identifies the importance of coalitions for analysis of the Brazilian electoral system. We believe these innovations show the way towards new research horizons, not least to fill in the many gaps we have left unfilled. These include the roles of governors, electoral behavior, and individual budget amendments.

Translated by Fraser Robinson

Submitted on May 05, 2018

Accepted on June 08, 2019

\section{References}

ABRAMOWITZ, Alan I. (1991), Incumbency, campaign spending, and the decline of competition in U.S. House Elections. The Journal of Politics. Vol. 53, № 01, pp. 34-56.

\footnotetext{
${ }^{26}$ According to some anonymous reviewers, this statement should have been weighed against the relevance of incumbent concentration in coalitions in our models. We saw no incompatibility, however, between bringing together governing coalition and the personalism of electoral contests. After all, a 'classic' argument in the literature is that the advantage of incumbents is gained via pork. Voters tend to reward parliamentarians who direct benefits to their base, something that is easier to achieve when you are a member of the coalition (PEREIRA and MUELLER, 2003).
} 
ABRAMOWITZ, Alan I.; ALEXANDER, Brad, and GUNNING, Matthew (2006), Incumbency, redistricting, and the decline of competition in U.S. House Elections. The Journal of Politics. Vol. 68, № 01, pp. 75-88.

ABRUCIO, Luiz F. and SAMUELS, David (1997), A nova política dos governadores. Lua Nova. № 40/41, pp. 137-166.

AMES, Barry (2003), Os entraves da democracia no Brasil. Rio de Janeiro: Editora FGV. 412 pp.

AMES, Barry (1995), Electoral rules, constituency pressures, and pork barrel: bases of voting in the Brazilian Congress. The Journal of Politics. Vol. 57, № 02, pp. 324-343.

AVELINO, George; BIDERMAN, Ciro, and BARONE, Leonardo (2012), Articulações intrapartidárias e desempenho eleitoral no Brasil. Dados. Vol. 55, № 04, pp. 987-1013.

AVELINO, George; BIDERMAN, Ciro; and SILVA, Glauco Peres da (2016), A concentração eleitoral nas eleições paulistas: medidas e aplicações. Dados. Vol. 54, № 02, pp. 319-347.

BLACK, Earl and BLACK, Merle (2002), The rise of southern republicans. Cambridge: Harvard University Press. 464 pp..

BOHN, Simone and PAIVA, Denise (2009), A volatilidade eleitoral nos Estados: sistema partidário e democracia no Brasil. Revista de Sociologia e Política. Vol. 17, № 33, pp. 187-208.

BORGES, André; PAULA, Carolina de, and SILVA, Adriano da Nóbrega (2016), Eleições legislativas e geografia do voto em contexto de preponderância do Executivo. Revista de Sociologia e Política. Vol. 24, № 58, pp. 31-58.

BRAGA, Maria do Socorro Souza (2006), O processo partidário eleitoral brasileiro: padrões de competição política (1982-2002). São Paulo: Humanitas FAPESP. $306 \mathrm{pp}$.

CAMPBELL, James E. and JUREK, Steven J. (2003), The decline of competition and change in Congressional Elections. In: Congress responds to the twentieth century. Edited by AHUJA, Sunil and DEWHIRST, Robert. Columbus: Ohio State University Press. pp. 43-72.

CAMPELLO, Daniela and ZUCCO, Cesar (2008), A esquerda em um país democrático, globalizado e desigual: uma análise do Brasil de Lula. In: Perspectivas analiticas sobre nuevos gobiernos y sociedad en America Latina. Edited by MOREIRA, C. et al. Montevideo: Trilice. pp. 97-124. 
CARAMANI, Daniele (2003), The end of silent elections: the birth of electoral competition, 1832-1915. Party Politics. Vol. 99, № 04, pp. 411-443.

CAREY, John M. and SHUGART, Matthew S. (1995), Incentives to cultivate a personal vote: a rank ordering of electoral formulas. Electoral Studies. Vol. 14, № 04 , pp. 417-439.

CARNEIRO, Leandro Piquet and ALMEIDA, Maria Hermínia Tavares de (2008), Definindo a arena política local: sistemas partidários municipais na federação brasileira. Dados. Vol. 51, № 02, pp. 403-432.

CARVALHO, Nelson Rojas (2003), E no início eram as bases: geografia política do voto e comportamento legislativo no Brasil. Rio de Janeiro: Revan. 222 pp..

COX, Gary W. (1997), Making votes count: strategic coordination in the world's electoral systems. Cambridge: Cambridge University Press. 360 pp..

COX, Gary W. and KATZ, Jonathan N. (2004) Elbridge Gerry's Salamander: the electoral consequences of the reapportionment revolution. Cambridge: Cambridge University Press. 248 pp..

COX, Gary W and KATZ, Jonathan N. (1996), Why did the incumbency advantage in U.S. House elections grow? American Journal of Political Science. Vol. 40, № 02, pp. 478-497.

DUVERGER, Maurice (1954), Political parties: their organization and activities in the modern state. London: Methuen. 439 pp..

FEREJOHN, John A. (1977), On the decline of competition in Congressional Elections. The American Political Science Review. Vol. 71, № 01, pp. 166-176.

FIGUEIREDO, Argelina Cheibub and LIMONGI, Fernando (2008), Política orçamentária no presidencialismo de coalizão. Rio de Janeiro: Ed. FGV. 184 pp..

FIORINA, Morris P. (1977), The case of the vanishing marginals: the bureaucracy did It. American Political Science Review. Vol. 71, № 01, p. 177-181.

GLAZER, Amihai; BERNARD, Grofman, and ROBBINS, Marc (1987), Partisan and incumbency effects of 1970s Congressional redistricting. American Journal of Political Science. Vol. 31, pp. 681-707.

GOLOSOV, Grigorii V. (2010), The effective number of parties: a new approach. Party Politics. Vol. 16, № 02, pp. 171-192.

GREENE, William H. (2008), Econometric analysis. Nova Jersey: Pearson/PrenticeHall. 1177 pp.. 
GUJARATI, Damodar N. and PORTER, Dawn C. (2011), Econometria Básica. Porto Alegre: AMGH. 918 pp..

HOLBROOK, Thomas M. and VON DUNK, Emily (1993), Electoral competition in American States. American Political Science Review. Vol. 87, № 04, pp. 955-962.

JACOB, Cesar Romero; HEES, D. R.; WANIEZ, P., and BRUSTLEIN, V. (2009), A eleição presidencial de 2006 no Brasil: continuidade política e mudança na geografia eleitoral. Alceu. Vol. 10, № 09, pp. 232-261.

JACOBSON, GARY C. (2007), A divider, not a uniter: George W. Bush and the American people. New York: Pearson Longman. 342 pp..

JACOBSON, Gary C. (1992), The politics of congressional elections. Nova York: Harper Collins Publishers. 280 pp..

JACOBSON, Gary C. (1989), Money in Congressional elections. New Haven: Yale University Press. 251 pp..

JACOBSON, Gary C. (1978). The effects of campaign spending in Congressional elections. American Political Science Review. Vol. 72, № 02, pp. 469-491.

KATZ, Richard S. (2005), Why are there so many (or so few) electoral reforms? In: The politics of electoral systems. Edited by GALLAGUER, Michael and $\mathrm{e}$ MITCHELL, Paul. Oxford: Oxford University Press. pp. 57-78.

KAZEE, Thomas A. (1983), The deterrent effect of incumbency on recruiting challengers in U.S. House elections. Legislative Studies Quarterly. Vol. 08, № 03, pp. 469-480.

KEY JR., Valdimer Orlando (1959), Secular realignment and the party system. Journal of Politics. Vol. 21, № 02, pp. 198-210.

KINZO, M. Dalva; MARTINS, José P.; BORIN, Ivan (2004), Patrones de competencia electoral en la disputa por la Cámara de Diputados en Brasil (1994-2002). América Latina Hoy. Vol. 38, pp. 143-162.

LAMOUNIER, Bolívar (1994), A democracia brasileira de 1985 à década de 90: a síndrome da paralisia hiperativa. In: Governabilidade, sistema político $e$ violência urbana. Edited by VELLOSO, J. P. dos Reis. Rio de Janeiro: José Olympio. pp. 25-64.

LEMOS, Leany Barreiros; MARCELINO, Daniel, and PEDERIVA, João Henrique (2010), Porque dinheiro importa: a dinâmica das contribuições eleitorais para o Congresso Nacional em 2002 e 2006. Opinião Pública. Vol. 16, № 02, pp. 366393. 
LIJPHART, Arend (1990), The political consequences of electoral laws, 1945-85. American Political Science Review. Vol. 84, № 02, pp. 481-496.

LIMONGI, Fernando P. (2006), A democracia no Brasil: presidencialismo, coalizão partidária e processo decisório. Novos Estudos CEBRAP. Vol. 76, pp. 17-41.

LYONS, Michael and GALDERISI, Peter F. (1995), Incumbency, reapportionment, and U.S. House redistricting. Political Research Quarterly. Vol. 48, № 04, pp. 857-871.

MAINWARING, Scott P. (2001), Sistemas partidários em novas democracias: o caso do Brasil. Rio de Janeiro: FGV. 420 pp..

MAINWARING, Scott P. (1998), Electoral volatility in Brasil. Party Politics. Vol. 04, № 04, pp. 523-545.

MAYHEW, David R. (1974), Congressional elections: the case of the vanishing marginal. Polity. Vol. 06, pp. 295-317.

MELO, Carlos Ranulfo (2004), Retirando as cadeiras do lugar: migração partidária na Câmara dos Deputados (1985-2002). Belo Horizonte: UFMG. 209 pp.

NICOLAU, Jairo (2006), 0 sistema eleitoral de lista aberta no Brasil. Dados. Vol. 49, № 04 , pp. 689-720.

PEIXOTO, Vitor de Moraes and GOULART, Nelson Luis Motta (2014), Evolução da competição eleitoral municipal no Brasil (1996 a 2012). Teoria e Pesquisa. Vol. 23, № 02, pp. 41-63.

PEREIRA, Carlos and MUELLER, Bernardo (2003), Partidos fracos na arena eleitoral e partidos fortes na arena legislativa: a conexão eleitoral no Brasil. Dados. Vol. 46, № 04, pp. 735-771.

PEREIRA, Carlos and RENNÓ, Lucio (2007), 0 que é que o reeleito tem? 0 retorno: o esboço de uma teoria da reeleição no Brasil. Revista de Economia e Política. Vol. 27, № 04, pp. 664-683.

PEREIRA, Carlos and RENNÓ, Lucio (2003), Successful re-election strategies in Brazil: the electoral impact of distinct institutional incentives. Electoral Studies. Vol. 22, № 03, pp. 425-448.

PEREIRA, Carlos and RENNÓ, Lucio (2001), o que é que o reeleito tem? Dinâmicas político-institucionais locais e nacionais nas eleições de 1998 para a Câmara dos Deputados. Dados. Vol. 44, № 02, pp. 133-172.

POLSBY, Nelson W. (2004), How Congress evolves: social bases of institutional change. New York: Oxford University Press. 272 pp.. 
RAE, Douglas W. (1967), The political consequences of electoral laws. New Haven: Yale University Press. 173 pp..

SAMUELS, David (2003), Ambition, federalism, and legislative politics in Brazil. Cambridge: Cambridge University Press. 266 pp..

SAMUELS, David (2001), Incumbents and challengers on a level playing field: assessing the impact of campaign finance in Brazil. Journal of Politics. Vol. 63, № 02 , pp. 569-584.

SAMUELS, David (2000) Ambition and competition: explaining legislative turnover in Brazil. Legislative Studies Quarterly. Vol. 25, № 03, pp. 481-497.

SANTOS, Fabiano (2003), o poder legislativo no presidencialismo de coalizão. Belo Horizonte: Editora UFMG. 251 pp..

SILVA, Glauco Peres da (2017), Mesmas instituições, mesmos resultados? Comparando o efeito da competição eleitoral sobre os níveis de concentração de voto. Opinião Pública. Vol. 23, № 03, pp. 682-713.

SILVA, Glauco Peres da (2013), Uma avaliação empírica da competição eleitoral na Câmara Federal no Brasil. Opinião Pública. Vol. 19, № 02, pp. 403-429.

SINCLAIR, Barbara (1982), Congressional realignment 1925-1978. Austin: University of Texas Press. 201 pp..

STOCK, James H. and WATSON, Mark W. (2004), Econometria. São Paulo: Pearson Addison Wesley. 485 pp..

STONECASH, Jeffrey M. (2008), Reassessing the incumbency effect. Cambridge: Cambridge University Press. 184 pp..

STONECASH, Jeffrey M. (2003), Reconsidering the trend in incumbent vote percentages in house elections. American Review of Politics. Vol. 24, № 01, pp. 225-239.

STONECASH, Jeffrey M; BREWER, Mark D., and MARIANI, Mack D. (2003), Diverging parties: social change, realignment, and party polarization. Boulder: Westview. 190 pp..

TAAGEPERA, Rein (1979), Inequality, concentration, imbalance. Political Methodology. Vol. 06, № 03, pp. 275-291.

TAAGEPERA, Rein and RAY, James Lee (1977), A generalized index of concentration. Sociological Methods and Research. Vol. 05, № 03, pp. 367-384.

TUFTE, Edward R. (1973), The relationship between seats and votes in two-party systems. American Political Science Review. Vol. 67, № 02, pp. 540-554. 
TUFTE, Edward R.; LEMIEUX, Peter H.; KORT, Fred; PFOTENHAUER, David; STEWART, Philip R., and BURNHAM, Walter Dean (1974), Communications. American Political Science Review. Vol. 68, pp. 202-213. 


\section{Annexes}

Table S01. Imbalance and concentration of vote by State (1990-2014)

\begin{tabular}{|c|c|c|c|c|c|c|c|c|c|c|c|}
\hline \multirow[t]{2}{*}{ State } & \multicolumn{7}{|c|}{ Vote imbalance } & \multicolumn{4}{|c|}{ Concentration of vote } \\
\hline & $\mathrm{N}$ & More & Less & Average & Deviation & $\mathrm{CV}$ & Less & More & Average & Deviation & $\mathrm{CV}$ \\
\hline $\mathrm{AC}$ & 7 & 0,079 & 0,232 & 0,157 & 0,064 & 40,602 & 0,028 & 0,070 & 0,044 & 0,014 & 31,737 \\
\hline AL & 7 & 0,055 & 0,198 & 0,126 & 0,055 & 43,929 & 0,038 & 0,067 & 0,048 & 0,010 & 21,776 \\
\hline $\mathrm{AM}$ & 7 & 0,082 & 0,293 & 0,163 & 0,086 & 52,521 & 0,052 & 0,075 & 0,063 & 0,008 & 13,036 \\
\hline AP & 7 & 0,051 & 0,253 & 0,155 & 0,080 & 51,589 & 0,011 & 0,040 & 0,031 & 0,010 & 31,686 \\
\hline $\mathrm{BA}$ & 7 & 0,080 & 0,277 & 0,162 & 0,074 & 45,591 & 0,013 & 0,020 & 0,017 & 0,003 & 16,508 \\
\hline $\mathrm{CE}$ & 7 & 0,048 & 0,542 & 0,173 & 0,168 & 97,355 & 0,024 & 0,045 & 0,030 & 0,007 & 23,626 \\
\hline DF & 7 & 0,099 & 0,487 & 0,230 & 0,147 & 63,959 & 0,017 & 0,113 & 0,054 & 0,031 & 56,509 \\
\hline ES & 7 & 0,012 & 0,482 & 0,177 & 0,156 & 88,317 & 0,029 & 0,061 & 0,036 & 0,012 & 32,278 \\
\hline GO & 7 & 0,059 & 0,257 & 0,169 & 0,073 & 43,069 & 0,026 & 0,034 & 0,030 & 0,003 & 11,595 \\
\hline MA & 7 & 0,031 & 0,080 & 0,053 & 0,017 & 31,559 & 0,020 & 0,032 & 0,026 & 0,005 & 19,030 \\
\hline$M G$ & 7 & 0,036 & 0,333 & 0,128 & 0,104 & 81,293 & 0,008 & 0,010 & 0,009 & 0,001 & 10,031 \\
\hline MS & 7 & 0,128 & 0,292 & 0,178 & 0,059 & 32,864 & 0,040 & 0,068 & 0,050 & 0,009 & 18,517 \\
\hline MT & 7 & 0,075 & 0,526 & 0,175 & 0,158 & 90,375 & 0,037 & 0,077 & 0,053 & 0,013 & 25,236 \\
\hline $\mathrm{PA}$ & 7 & 0,080 & 0,547 & 0,248 & 0,173 & 69,805 & 0,022 & 0,039 & 0,031 & 0,007 & 21,842 \\
\hline PB & 7 & 0,032 & 0,448 & 0,129 & 0,151 & 116,826 & 0,033 & 0,057 & 0,043 & 0,009 & 20,980 \\
\hline PE & 7 & 0,064 & 0,448 & 0,188 & 0,152 & 80,723 & 0,021 & 0,081 & 0,035 & 0,022 & 62,509 \\
\hline PI & 7 & 0,051 & 0,190 & 0,099 & 0,056 & 56,876 & 0,046 & 0,062 & 0,054 & 0,007 & 12,315 \\
\hline PR & 7 & 0,016 & 0,290 & 0,108 & 0,121 & 111,932 & 0,012 & 0,059 & 0,021 & 0,017 & 81,014 \\
\hline RJ & 7 & 0,015 & 0,510 & 0,168 & 0,161 & 95,860 & 0,008 & 0,417 & 0,068 & 0,154 & 224,780 \\
\hline RN & 7 & 0,076 & 0,303 & 0,157 & 0,097 & 61,700 & 0,053 & 0,091 & 0,069 & 0,013 & 18,259 \\
\hline RO & 7 & 0.057 & 0.283 & 0.131 & 0.087 & 66.732 & 0.024 & 0.049 & 0.035 & 0.007 & 21.477 \\
\hline $\mathrm{RR}$ & 7 & 0.087 & 0.601 & 0.280 & 0.186 & 66.368 & 0.038 & 0.077 & 0.056 & 0.014 & 25.001 \\
\hline RS & 7 & 0.016 & 0.362 & 0.134 & 0.113 & 84.403 & 0.011 & 0.019 & 0.014 & 0.003 & 18.791 \\
\hline SC & 7 & 0.046 & 0.249 & 0.103 & 0.071 & 69.237 & 0.019 & 0.037 & 0.026 & 0.006 & 24.814 \\
\hline SE & 7 & 0.071 & 0.261 & 0.154 & 0.076 & 49.510 & 0.042 & 0.062 & 0.055 & 0.007 & 12.548 \\
\hline SP & 7 & 0.064 & 0.547 & 0.267 & 0.187 & 70.026 & 0.005 & 0.012 & 0.009 & 0.003 & 36.517 \\
\hline TO & 7 & 0.051 & 0.285 & 0.164 & 0.088 & 53.725 & 0.036 & 0.078 & 0.055 & 0.013 & 23.249 \\
\hline
\end{tabular}

Source: Prepared by the authors based on Superior Electoral Court. 
Table S02. Concentration and proportion of incumbent candidates (1990-2014)

\begin{tabular}{|c|c|c|c|c|c|c|c|c|c|c|c|}
\hline \multirow[t]{2}{*}{ State } & \multicolumn{6}{|c|}{ Concentration of incumbents } & \multicolumn{5}{|c|}{ Proportion of incumbents } \\
\hline & $\mathrm{N}$ & Minimum & Maximum & Average & Deviation & $\mathrm{CV}$ & Minimum & Maximum & Average & Deviation & $\mathrm{CV}$ \\
\hline $\mathrm{AC}$ & 7 & 0.004 & 0.135 & 0.043 & 0.053 & 123.639 & 0.015 & 0.180 & 0.072 & 0.055 & 76.58 \\
\hline $\mathrm{AL}$ & 7 & 0.020 & 0.127 & 0.073 & 0.040 & 54.822 & 0.050 & 0.125 & 0.086 & 0.027 & 31.05 \\
\hline $\mathrm{AM}$ & 7 & 0.030 & 0.174 & 0.101 & 0.056 & 55.478 & 0.063 & 0.146 & 0.099 & 0.032 & 32.31 \\
\hline AP & 7 & 0.002 & 0.109 & 0.064 & 0.036 & 56.669 & 0.013 & 0.159 & 0.090 & 0.042 & 46.64 \\
\hline $\mathrm{BA}$ & 7 & 0.147 & 0.880 & 0.387 & 0.255 & 65.908 & 0.099 & 0.263 & 0.160 & 0.045 & 28.36 \\
\hline $\mathrm{CE}$ & 7 & 0.072 & 0.251 & 0.142 & 0.064 & 45.002 & 0.077 & 0.167 & 0.127 & 0.032 & 25.35 \\
\hline DF & 7 & 0.014 & 0.357 & 0.078 & 0.124 & 158.493 & 0.023 & 0.095 & 0.048 & 0.023 & 47.50 \\
\hline ES & 7 & 0.015 & 0.117 & 0.052 & 0.034 & 65.255 & 0.032 & 0.111 & 0.068 & 0.028 & 42.12 \\
\hline $\mathrm{GO}$ & 7 & 0.063 & 0.226 & 0.119 & 0.062 & 52.144 & 0.078 & 0.146 & 0.107 & 0.022 & 21.03 \\
\hline MA & 7 & 0.026 & 0.225 & 0.114 & 0.060 & 53.142 & 0.034 & 0.152 & 0.095 & 0.038 & 39.79 \\
\hline MG & 7 & 0.074 & 0.338 & 0.159 & 0.088 & 55.525 & 0.058 & 0.131 & 0.091 & 0.021 & 23.09 \\
\hline MS & 7 & 0.015 & 0.316 & 0.081 & 0.107 & 131.683 & 0.046 & 0.175 & 0.076 & 0.036 & 47.15 \\
\hline MT & 7 & 0.013 & 0.123 & 0.073 & 0.036 & 48.894 & 0.042 & 0.147 & 0.091 & 0.033 & 36.60 \\
\hline PA & 7 & 0.072 & 0.315 & 0.163 & 0.081 & 49.738 & 0.075 & 0.135 & 0.108 & 0.021 & 19.51 \\
\hline PB & 7 & 0.036 & 0.380 & 0.126 & 0.119 & 94.543 & 0.089 & 0.146 & 0.111 & 0.018 & 16.27 \\
\hline $\mathrm{PE}$ & 7 & 0.089 & 0.310 & 0.195 & 0.071 & 36.334 & 0.107 & 0.182 & 0.132 & 0.027 & 20.65 \\
\hline PI & 7 & 0.050 & 0.154 & 0.087 & 0.037 & 42.535 & 0.088 & 0.171 & 0.112 & 0.027 & 24.08 \\
\hline PR & 7 & 0.016 & 0.220 & 0.137 & 0.077 & 56.216 & 0.047 & 0.118 & 0.095 & 0.025 & 26.66 \\
\hline $\mathrm{RJ}$ & 7 & 0.039 & 0.191 & 0.098 & 0.050 & 51.008 & 0.035 & 0.103 & 0.059 & 0.019 & 32.02 \\
\hline RN & 7 & 0.046 & 0.159 & 0.108 & 0.042 & 38.981 & 0.072 & 0.174 & 0.099 & 0.030 & 30.01 \\
\hline RO & 7 & 0.008 & 0.066 & 0.034 & 0.019 & 55.793 & 0.015 & 0.100 & 0.056 & 0.027 & 47.63 \\
\hline $\mathrm{RR}$ & 7 & 0.000 & 0.177 & 0.088 & 0.061 & 69.562 & 0.000 & 0.184 & 0.076 & 0.051 & 66.91 \\
\hline RS & 7 & 0.090 & 0.257 & 0.172 & 0.075 & 43.564 & 0.081 & 0.119 & 0.105 & 0.012 & 11.20 \\
\hline SC & 7 & 0.074 & 0.177 & 0.105 & 0.033 & 31.907 & 0.075 & 0.141 & 0.099 & 0.019 & 18.84 \\
\hline SE & 7 & 0.000 & 0.109 & 0.051 & 0.036 & 70.580 & 0.000 & 0.125 & 0.085 & 0.021 & 25.16 \\
\hline SP & 7 & 0.057 & 0.219 & 0.124 & 0.061 & 48.787 & 0.037 & 0.087 & 0.064 & 0.016 & 24.78 \\
\hline TO & 7 & 0.000 & 0.108 & 0.063 & 0.037 & 58.659 & 0.000 & 0.182 & 0.096 & 0.054 & 55.86 \\
\hline
\end{tabular}

Source: Prepared by the authors based on Superior Electoral Court. 
Graphs illustrating electoral competition measures with and without highest proportion of votes:

Graph S01. Comparison of averages imbalance

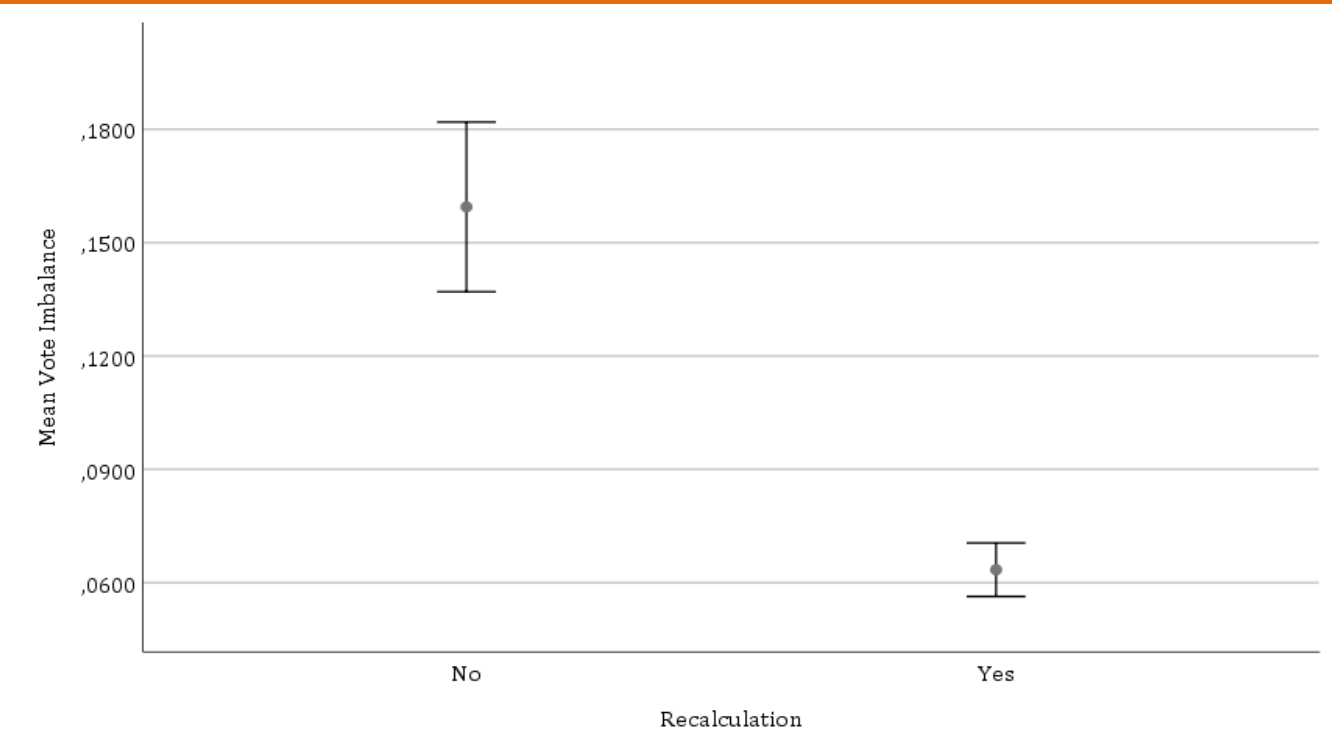

Source: Prepared by the authors based on Superior Electoral Court. Notes: Dif. $=0.096 \mathrm{p}=0.000$

Graph S02. Comparison of averages concentration

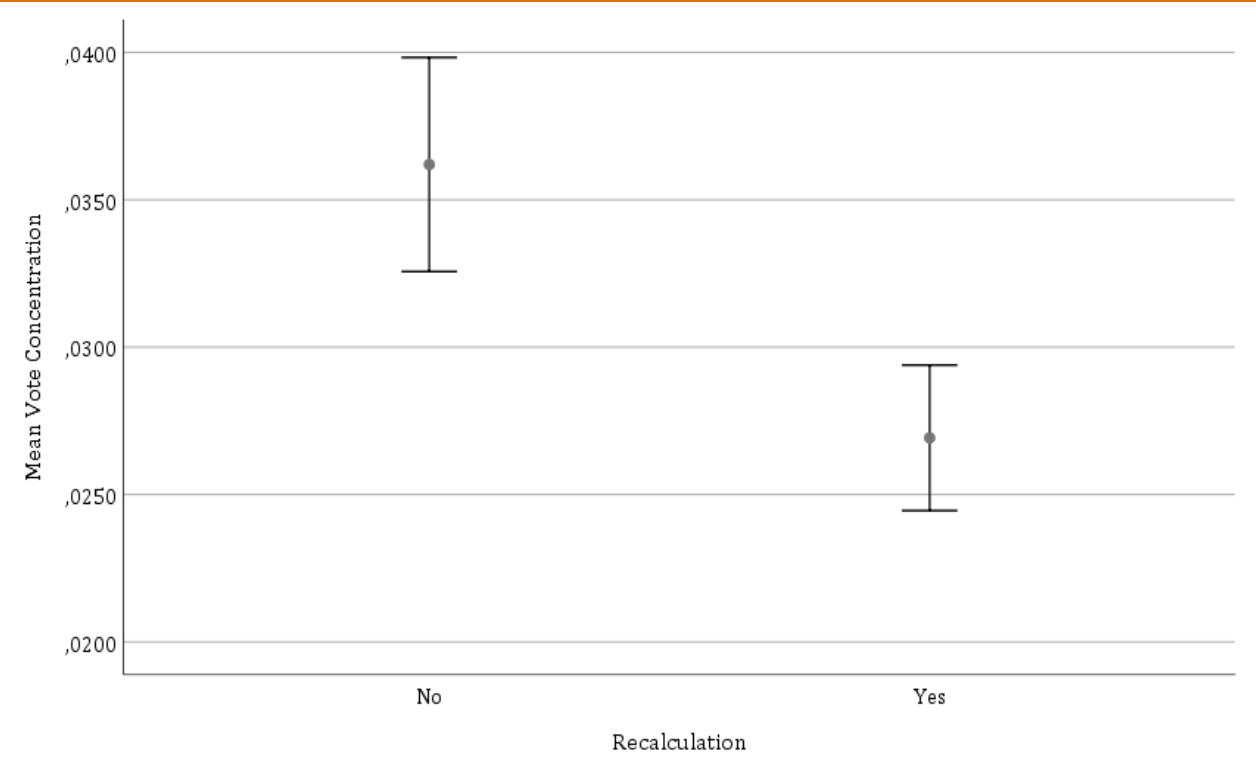

Source: Prepared by the authors based on Superior Electoral Court.

Notes: Dif. $=0.009 p=0.000$ 
Comparison between OLS and WLS models:

Graph S03. Variance of residues model (1)

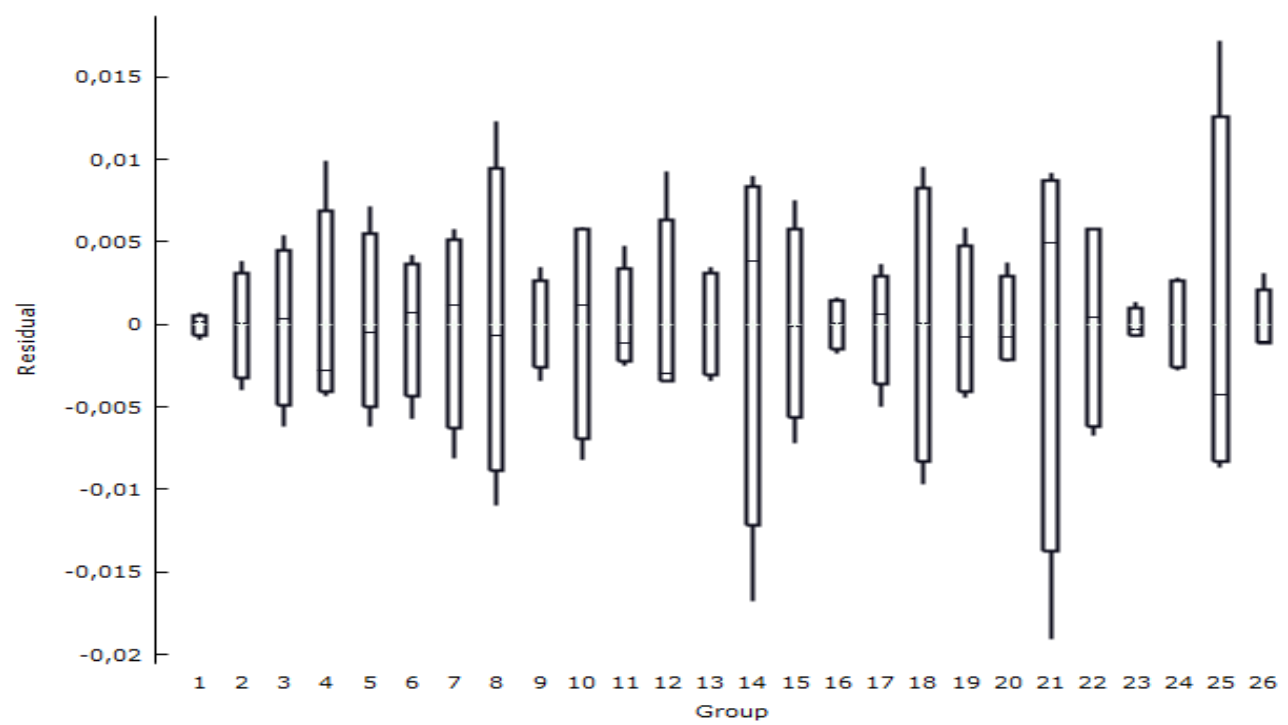

Source: Prepared by the authors based on Superior Electoral Court.

Graph S04. Variance of residues model (3)

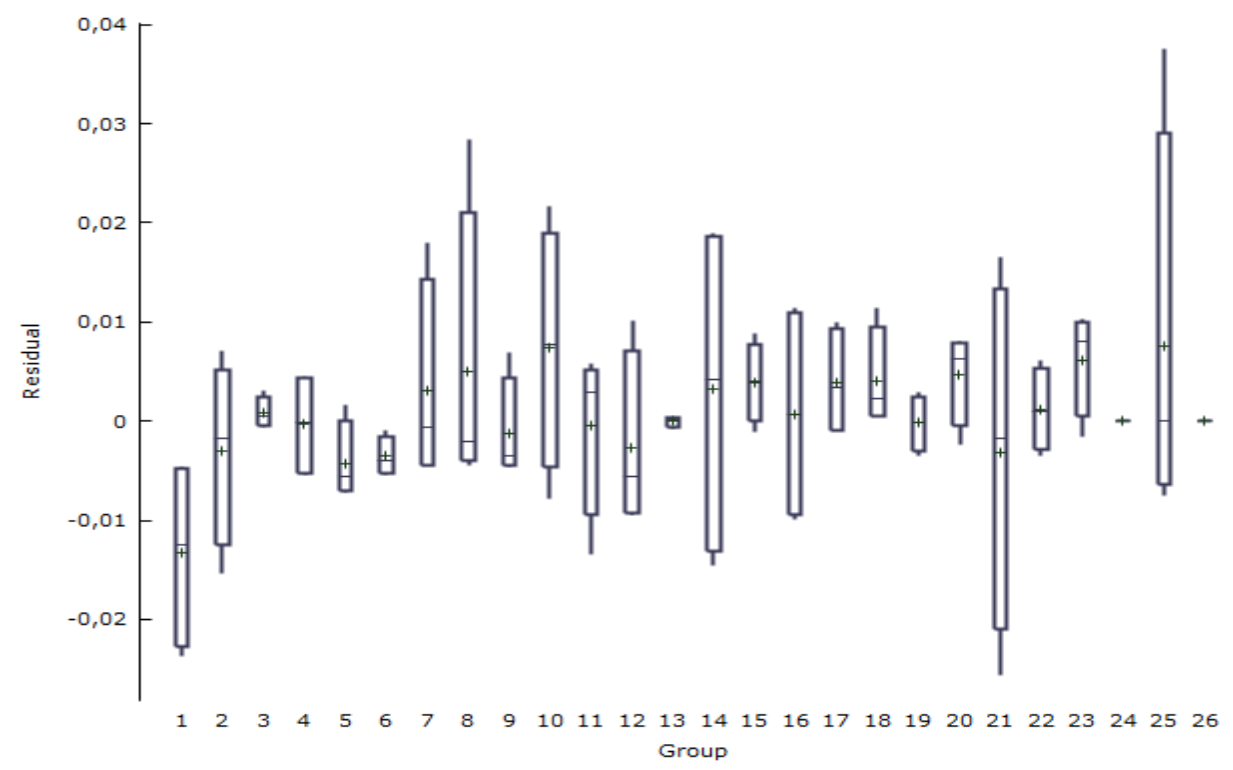

Source: Prepared by the authors based on Superior Electoral Court. 
Model with natural imbalance logarithm:

Table S03. Model 11: WLS, using 104 observations

\begin{tabular}{llllll} 
& Coefficient & Standard error & ratio-t & p-value & \\
\hline const & -2.17404 & 0.538019 & -4.041 & 0.0001 & $* * *$ \\
CONCINC & -2.46971 & 0.971148 & -2.543 & 0.0127 & $* *$ \\
PERCINC & -0.0280917 & 0.0426765 & -0.6582 & 0.5121 & \\
CONCREC & 11.1794 & 5.37614 & 2.079 & 0.0405 & $* *$ \\
ELECTORATE & $4.86824 \mathrm{e}-08$ & $8.23713 \mathrm{e}-08$ & 0.5910 & 0.5560 & \\
PIBPERC & 0.00179157 & 0.0117635 & 0.1523 & 0.8793 & \\
IMBALANCE & 0.000399351 & 0.00259331 & 0.1540 & 0.8780 & \\
PerSmaMun & -0.00461453 & 0.00356103 & -1.296 & 0.1984 & \\
PerIncCoa & -0.157221 & 0.0597726 & -2.630 & 0.0101 & $* *$ \\
PerCandGov & 0.0148827 & 0.0161349 & 0.9224 & 0.3588 & \\
PerCandPartG & 0.00108449 & 0.00462369 & 0.2346 & 0.8151 & \\
dt_2 & -0.204041 & 0.166864 & -1.223 & 0.2247 & \\
dt_3 & -0.0462451 & 0.211343 & -0.2188 & 0.8273 & \\
dt_4 & -0.219416 & 0.175914 & -1.247 & 0.2156 & \\
PercIncConcrec & -0.640431 & 0.551897 & -1.160 & 0.2490 & \\
PercIncPercIncCoa & 0.0154771 & 0.00446693 & 3.465 & 0.0008 & $* * *$ \\
\hline
\end{tabular}

Source: Prepared by the authors based on Superior Electoral Court.

Notes: Including 26 transverse cutting units; Dependent variable: DESLOGN; Weightings based on error variances per unit.

Statistics based on weighted data:

\begin{tabular}{lcll}
\hline Sum resid. squared & 100.0949 & E.P. of regression & 1.066509 \\
R-squared & 0.407289 & R-squared adjusted & 0.306259 \\
F(15, 88) & 4.031358 & P-valor(F) & 0.000016 \\
Likelihood log & -145.5794 & Akaike criterion & 323.1589 \\
Schwarz criterion & 365.4691 & Hannan-Quinn criterion & 340.3000 \\
\hline
\end{tabular}

Statistics based on original data:

\begin{tabular}{lrlr}
\hline Average depend. var. & -2.136346 & D.P. dependent var. & 0.762868 \\
Sum resid. squared & 50.08360 & E.P. of regression & 0.754408
\end{tabular}

